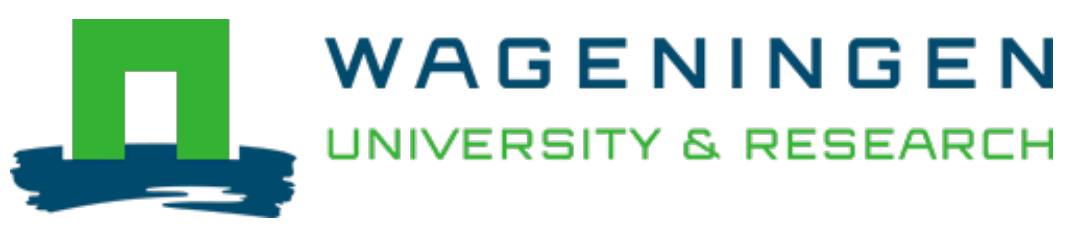

\title{
Observation and simulation of water movement and runoff in a coarse texture water repellent soil
}

Catena

Mirbabaei, Seyedeh Mehrnoosh; Shabanpour, Mahmoud; Dam, Jos; Ritsema, Coen; Zolfaghari, Aliasghar et al

https://doi.org/10.1016/j.catena.2021.105637

This publication is made publicly available in the institutional repository of Wageningen University and Research, under the terms of article $25 \mathrm{fa}$ of the Dutch Copyright Act, also known as the Amendment Taverne. This has been done with explicit consent by the author.

Article 25 fa states that the author of a short scientific work funded either wholly or partially by Dutch public funds is entitled to make that work publicly available for no consideration following a reasonable period of time after the work was first published, provided that clear reference is made to the source of the first publication of the work.

This publication is distributed under The Association of Universities in the Netherlands (VSNU) 'Article $25 \mathrm{fa}$ implementation' project. In this project research outputs of researchers employed by Dutch Universities that comply with the legal requirements of Article 25fa of the Dutch Copyright Act are distributed online and free of cost or other barriers in institutional repositories. Research outputs are distributed six months after their first online publication in the original published version and with proper attribution to the source of the original publication.

You are permitted to download and use the publication for personal purposes. All rights remain with the author(s) and / or copyright owner(s) of this work. Any use of the publication or parts of it other than authorised under article $25 \mathrm{fa}$ of the Dutch Copyright act is prohibited. Wageningen University \& Research and the author(s) of this publication shall not be held responsible or liable for any damages resulting from your (re)use of this publication.

For questions regarding the public availability of this publication please contact openscience.library@wur.nl 


\title{
Observation and simulation of water movement and runoff in a coarse texture water repellent soil
}

\author{
Seyedeh Mehrnoosh Mirbabaei ${ }^{\mathrm{a}, \mathrm{b}}$, Mahmoud Shabanpour ${ }^{\mathrm{a}, *}$, Jos van Dam ${ }^{\mathrm{b}}$, Coen Ritsema ${ }^{\mathrm{b}}$, \\ Aliasghar Zolfaghari ${ }^{\mathrm{c}}$, Mohammadreza Khaledian ${ }^{\mathrm{d}, \mathrm{e}}$ \\ a Department of Soil Science, University of Guilan, 41635-1314 Rasht, Iran \\ ${ }^{\mathrm{b}}$ Department of Soil Physics and Land Management, Wageningen University and Research, P.O. Box 47, 6700 AA Wageningen, the Netherlands \\ ${ }^{\mathrm{c}}$ Faculty of Desert Studies, Semnan University, Semnan, Iran \\ ${ }^{\mathrm{d}}$ Department of Water Eng., University of Guilan, P.O. BOX 41635-3756, Rasht, Iran \\ ${ }^{\mathrm{e}}$ Department of Water Engineering and Environment, Caspian Sea Basin Research, Iran
}

\section{A R T I C L E I N F O}

\section{Keywords:}

Water repellent soil

SWAP

Runoff

Infiltration

Evaporation

\begin{abstract}
A B S T R A C T
Water repellent or non-wetting soils show poor water infiltration, which leads to an increased runoff in both natural and agricultural setting. Some forest areas of northern Iran are characterized by extreme water repellency, which makes their soil hydrological response highly complex. A field experiment was carried out to study the effect of water repellency on water movement and runoff in coarse-textured soil covered in Pinus teada in northwestern Iran. An adapted version of the popular agrohydrological model SWAP (Soil, Water, Atmosphere and Plant) has been used to evaluate the modelling of soil water flow and runoff generation. Water repellency was accounted for by multiplying the soil water content and the unsaturated hydraulic conductivity of soil with the $\mathrm{F}$ factor. This factor is equal to the volumetric fraction of soil occupied by preferential flow paths. Twentyseven rainfall experiments were carried out under artificial rainfall using soils with various wettability levels and various rainfall intensities $(14 \mathrm{~mm} / \mathrm{h}, 27 \mathrm{~mm} / \mathrm{h}$ and $34 \mathrm{~mm} / \mathrm{h})$. The result show that during the summer and early autumn (May to October) the soil became extreme repellent and runoff was formed when the soils were dry $(\theta<2 \%)$ and the rain intensity was more than $27 \mathrm{~mm} / \mathrm{h}$. Also, we investigated the role of the repellent layer on evaporation losses. The results of laboratory and simulation data confirm that water repellency reduces evaporation from the soil surface. Comparing modelling results with field data shows that an assumption of uniform flow in water repellent soil leads to an overestimation of soil water content and an underestimation of runoff. After incorporating water repellency in SWAP with the mobile-immobile concept, the agreement between measured and model simulation data considerably improved.
\end{abstract}

\section{Introduction}

Soil water repellency (SWR) or hydrophobicity has received increasing attention in recent years. It is one of the unstable micro-scale phenomena that seriously affects water movement in soil (Wallach, 2010). Dry water repellent soil resists or slows down water infiltration into the soil matrix on time scales ranging from seconds to days. This phenomenon has been reported for a variety of soil types, land uses, and climatic conditions worldwide (Bachmann et al., 2001; Doerr et al., 1998).

Naturally, dry soils easily absorb water and become saturated. There is a strong attraction between soil and water mineral particles, the intensity of which depends on the difference between the soil surface tension and the liquid surface tension (DeBano, 1981). Soil water repellency is a dynamic phenomenon that is caused by low-energy surfaces where the attraction between solid and liquid phases is weak. When the tension forces between water and soil are neutralized or disappear due to the presence of a repellent coating on sand grains or an aggregate, soils resist infiltration and become repellent (chau et al., 2014).

It is generally accepted that various organic molecules are potentially responsible for the hydrophobic properties of water repellent soils (Almendros et al., 1988). In addition to soil organic matter, many researchers have considered soil texture as an important and effective

\footnotetext{
* Corresponding author.

E-mail address: Shabanpour@guilan.ac.ir (M. Shabanpour).
} 
parameter in the formation and intensity of water repellency (BadiaVillas et al., 2014; Mirbabaei et al., 2013). This phenomenon is more frequently observed in sandy soils than in other soil textures (Mao et al., 2019). Because of the low specific surface area of sand particles, the small amount of repellent organic materials would be sufficient to coat coarse soil particles as compared to the fine soil particles (Blackwell, 1993). However, severe water repellency has also been reported in soils with considerable clay content. This is due to the coating of aggregate surfaces in clay with hydrophobic materials (Chan, 1992).

In water repellent soils, water movement and the infiltration wetting front develop into fingers, causing preferential flow instead of uniform flow (Ritsema et al., 2005). Finger flow is an irregular, special wetting front shaped like fingers through which water moves unevenly (Rezanezhad et al., 2006). The correct description of soil water movement in the unsaturated zone requires knowledge of the soil hydraulic properties. These relationships have been modelled using analytical solutions of Richards' flow equations in 1-D for porous and unsaturated soils (Philip, 1957; Smith, 2002) and are easily incorporated into hydrological models. However, these analytical solutions may not represent the actual relations for soils affected by water repellency.

Some researchers have investigated the movement of water in repellent soil using simulations, which are usually based on a parameterization of retention curves. Deurer and Bachmann (2007) applied a conceptual numerical model to simulate water movement in heterogeneous water repellent soils. They showed that infiltration into the soil profile was highly sensitive to the degree and persistence of water repellency. Nunes et al. (2016) adapted soil water repellency of a daily water balance model on unburned and burned eucalypt plantations in northern Portugal. Moody and Ebel (2014) investigated runoff in postwildfire areas by combining field measurements and infiltration modelling. They used a numerical model, Hydrus 1-D, to estimate postwildfire infiltration and runoff within the unsaturated zone.

Among the vadose zone models, the agrohydrological SWAP (Soil, Water, Atmosphere and Plant) model addresses the close interactions between soil water flow, surface water management, and vegetation development. Unstable flow in water repellent soils has been studied by Hendricks et al. (1988) and Van Dam et al. (1996). They stated that an unstable wetting front in repellent soil causes irregular flow and finger flow in these soils. Only a part of the soil matrix actively participates in the flow process. The process of finger flow was incorporated into the SWAP model by implementing the mobile-immobile concept. Wessolek et al (2007) studied percolation behavior in a pine forest on waterrepellent sandy soil. They used a one-dimensional numerical model SWAP. 2 to simulate mean water balance with hydraulic functions. They used the traditional piston flow concept for wettable soil and the mobile-immobile concept for water repellency.

Water movement in repellent soils (preferential flow) can be simulated with both the SWAP and HYDRUS models. The advantage of SWAP as compared to HYDRUS is that SWAP includes the crop growth model WOFOST. This makes SWAP suitable to analyse preferential flow in different agrohydrological and ecohydrological environments (Van Dam et al., 2008).

Many parts of the coastal sand site in the north of Iran are covered with Pinus teada. This species has been known to create water repellency in soils (Leelamanie, 2016). The Pinus teada shelterbelt along the coastal dunes has proven its ability to serve as a coastal protection barrier. However, the hydrophobic aspects and hydrological consequences of this shelterbelt, especially its effect on runoff production, are still unclear. Therefore, it is important to understand how SWR affects hydrological processes in Pinus teada forests. Previously, SWAP has been used to assess the infiltration process for water repellent sandy soils but the runoff process has not yet been assessed for repellent soil. The main purpose of this study is to investigate water flow and runoff in the sandy forest soils, using an adapted SWAP.4 model. The mobile-immobile concept was used to investigate the effect of soil water repellency on soil water fluxes and runoff.

\section{Material and methods}

\subsection{Study sites and basic soil properties}

This research was conducted in cultivated Pinus teada woodlands at a coastal site. This site can be considered as representative of reforestation, which has been widely applied in the past few decades to stop land degradation. The experimental site is located in the northwest of Iran $\left(37^{\circ} 52^{\prime} 55.0^{\prime \prime} \mathrm{N} ; 48^{\circ} 56^{\prime} 07.0^{\prime \prime} \mathrm{E}\right)$ (Fig. 1).

The study site comprises 20 ha and has been forested for more than 50 years with Pinus teada. The surface slope is slight (2\%). The study area has not been burned for at least 50 years. The climate of the study area is typically humid subtropical with the largest rainfall in Iran. The moisture and temperature regimes are Udic and Thermic, respectively. The weather data (daily air temperature, radiation, humidity, rainfall, air pressure and wind speed) were collected from a nearby weather station (at Talesh Meteorological Station).

The observation of piezometers in the area showed that the groundwater level is at a depth of $8 \mathrm{~m}$. The total rainfall during the measurement period (August 2017-July 2018) was $733.4 \mathrm{~mm}$. The months with the highest rainfall include October, May and September with $149.6,102.2$, and $100 \mathrm{~mm}$ of rainfall, respectively. The lowest rainfall occurred in June and July with values of 24.3 and $19 \mathrm{~mm}$, respectively. There is a dry period from June until mid-August due to high evaporation rates and this dry period alternates with heavy rainfalls occurring in autumn (Fig. 2)

The soil was classified as sandy, Typic Psammaquent. Three soil layers were distinguished $(0-15,15-40$ and $40-250 \mathrm{~cm})$ in the soil profile. Soil water repellency is a dynamic feature and has seasonal variations, so the model simulation was divided into three periods. The first period was set from the beginning of August to the end of October, the second period from the beginning of November to the end of April and the third period from the beginning of May to the end of July. Variation of soil water content and water repellency in the layers were measured at different times During the simulation process, soil samples were taken at three depths in vertical transects on the days $1,5,14,21$, $30,40,47,53,60,66,71,78,88,92,100,107,116,147,163,199,222$, 260, 288, 307, 325, 344 and 351, starting in August 2017 and lasting until July 2018. The soil samples were collected at $0-15 \mathrm{~cm}$ and $15-40$ $\mathrm{cm}$ using sharpened steel cylinders with a length of $5 \mathrm{~cm}$ and a diameter of $5 \mathrm{~cm}$. The cylinders were pressed into the soil vertically, emptied into plastic bags and used again. The plastic bags were tightly sealed to minimize evaporation from the soil. For the depth of $40-250 \mathrm{~cm}$, several augur holes were drilled to a depth of $1.5 \mathrm{~m}$ and samples were taken from every $10 \mathrm{~cm}$ of vertical distance. Because the soil was sandy, drilling holes was not that difficult. Deeper than $1.5 \mathrm{~m}$, soil samples were taken with a gouge (diameter $5 \mathrm{~cm}$, working length $30 \mathrm{~cm}$ ). In this way, soil samples were collected to a depth of about $1.8 \mathrm{~m}$. The core was divided into $10 \mathrm{~cm}$ sections and the samples empited into plastic bags. Since the changes in soil water content from a depth of $100 \mathrm{~cm}$ onwards were relatively small, the amount of soil water at a depth of $180 \mathrm{~cm}$ was considered for a depth of $180-250 \mathrm{~cm}$. Also several profiles were drilled in this site, sampling to a depth of $250 \mathrm{~cm}$ confirmed that changes in soil water content from a depth of $180-250 \mathrm{~cm}$ were relatively small. Thus, the amount of soil water at a depth of $40-250 \mathrm{~cm}$ was estimated. The groundwater level is very deep in this area and capillary rise does not occur. At each depth, 3 adjacent samples were taken over a horizontal distance of approximately $15 \mathrm{~cm}$. The field-moist soil in the plastic bags was weighed and the persistence of actual water repellency was measured. The samples were oven-dried and weighed to calculate the volumetric soil water content. The persistence and intensity of soil water repellency (SWR) were measured under field conditions using the Water Drop Penetration Time Test (WDPT) (Doerr et al., 1998). This was done by placing 3 drops of distilled water onto the smooth surface of the soil and measuring the average time it took for the drops to completely collapse and infiltrate into the sample (DeBano, 1981; Daniel et al., 

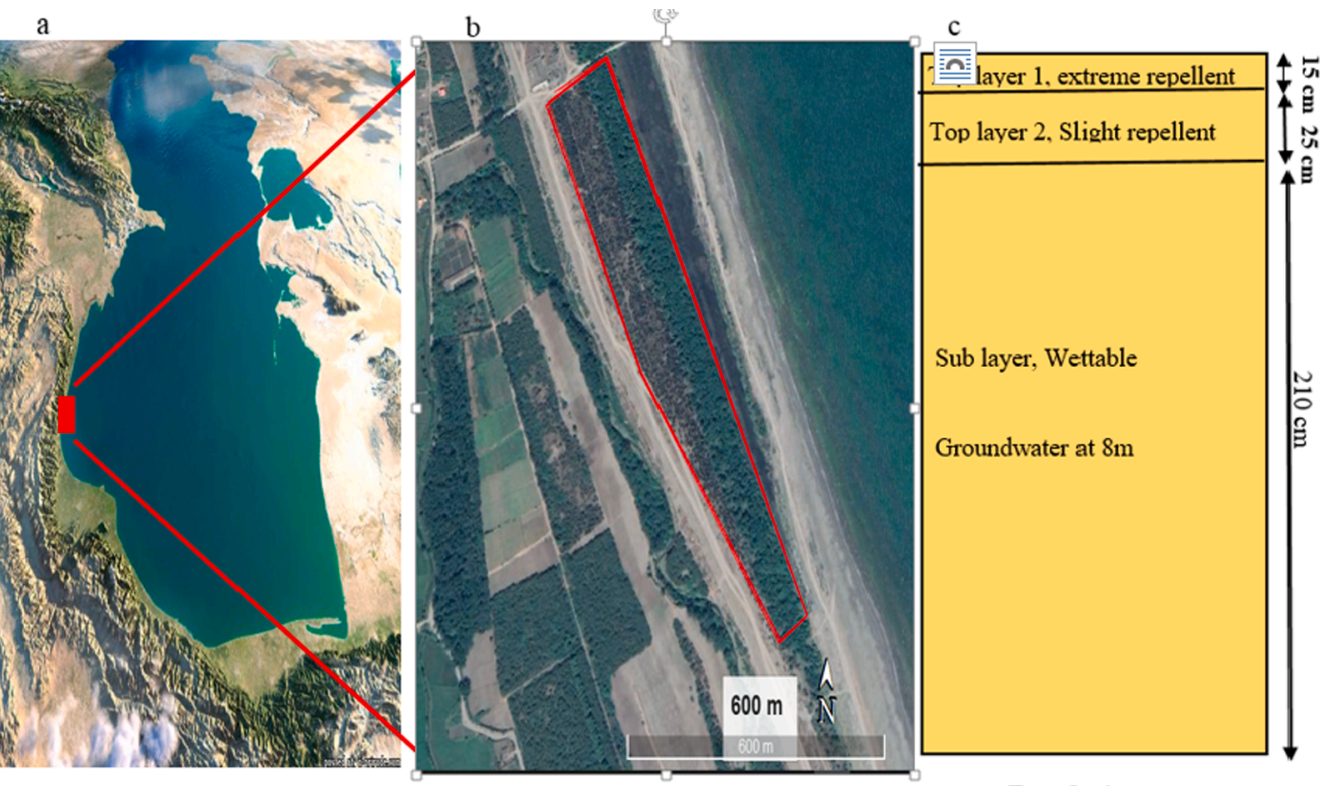

Free drainage

Fig. 1. Illustration of the location of the study site (a) in the northwest of Iran (b) shows exact positioning of the study site (20 ha) (c) Specifications and soil layering to a depth of $250 \mathrm{~cm}$.

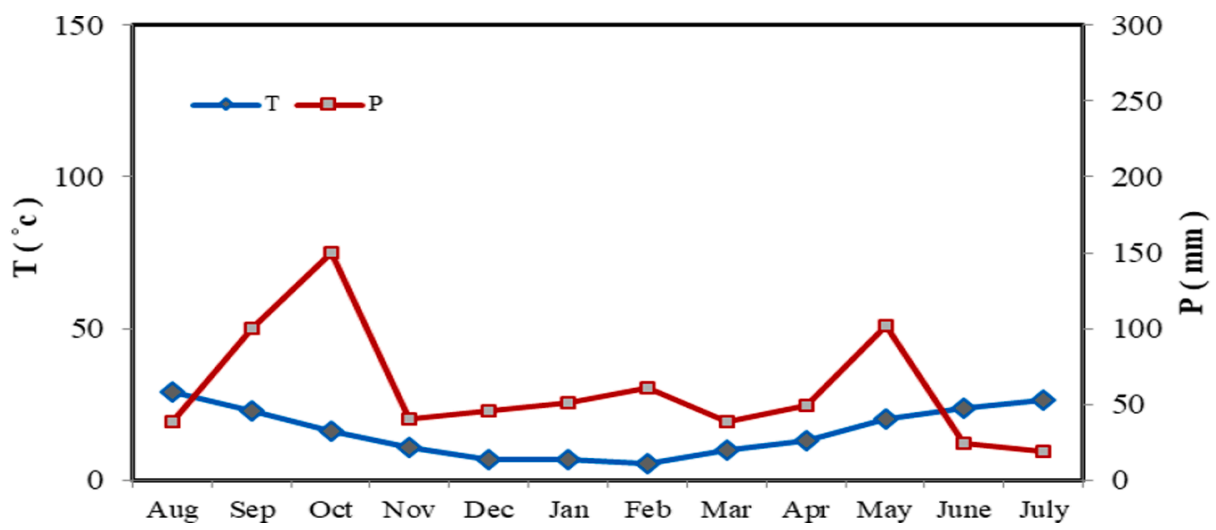

Fig. 2. The ambrotermic curve, (T) monthly temperature, (P) monthly precipitation recorded in the weather station of Talesh (Guilan) during the simulation period (August 2017-July 2018).

2019). According to the results of the WDPT, a soil was classified as wettable (WDPT $<5$ s), slightly water repellent ( $5 \mathrm{~s}<$ WDPT $<60 \mathrm{~s}$ ), strongly water repellent $(60 \mathrm{~s}<\mathrm{WDPT}<600 \mathrm{~s})$, severely water repellent $(600 \mathrm{~s}<\mathrm{WDPT}<3600 \mathrm{~s})$ and extremely water repellent (WDPT $>3600$ s).

Soil samples were air dried and passed through a $2 \mathrm{~mm}$ sieve to remove larger rock particles and were then analyzed in triplicate, and the mean values were considered representative for each case. Soil characterization was carried out by measuring the texture (sand, silt and clay percentages) which was determined using the hydrometer method (Gee and Or, 2002), and soil organic matter (OM) which was determined by burning all organic matter in the soil at a temperature of $450{ }^{\circ} \mathrm{C}$ (Davies, 1974). Bulk density was calculated on triple samples for each plot as the weight of soil in a given volume of the core extracted by a small cylinder (Klute, 1986).

The hydraulic conductivity of each soil layer $(0-15 \mathrm{~cm}, 15-40 \mathrm{~cm}$, $40-250 \mathrm{~cm}, \mathrm{n}=3$ ) was measured at the experimental site using a mini disk infiltrometer (Robichaud et al., 2008; Balfour, 2015).

Twenty-one tension infiltration tests were conducted using a standard MDI (Decagon Devices, Inc., Pullman, WA). The applied pressure of the device was set at $-2 \mathrm{~cm}$ to reduce the macro flow. Measurement duration was the time required for $30-40 \mathrm{~cm}^{3}$ to infiltrate into the soil; if no water infiltrated, the measurement was stopped after 15-20 min. More details about the experiment can be found in Balfour, 2015; Robichaud et al., 2008; and Weninger et al., 2019. The measured cumulative infiltration values (I, $[\mathrm{m}]$ ) were fitted against the infiltration time $(\mathrm{t},[\mathrm{s}])$, using Equation

$\mathrm{I}=\mathrm{C}_{1} \mathrm{t}+\mathrm{C}_{2} \sqrt{\mathrm{t}}$

The coefficients $C_{1}(\mathrm{~m} / \mathrm{s})$ and $C_{2}\left(\mathrm{~m} / \mathrm{s}^{1 / 2}\right)$ are fitting parameters. The best-fitting parameters were determined by the minimized sum of square error (SSE) between the model (Equation (1)) and the measured infiltration data. Coefficient $\mathrm{C}_{1}$ is related to soil hydraulic conductivity (SHC), and $\mathrm{C}_{2}$ is the soil sorptivity (Pullman, 2012). Soil hydraulic conductivity $(\mathrm{K},[\mathrm{mm} / \mathrm{h}])$ using mini disk infiltrometer data was calculated using the following equation:

$\mathrm{K}=\frac{\mathrm{C}_{1}}{\mathrm{~A}}$

Equations (3) and (4) were proposed by Zhang (1997). Coefficient A is a unitless $(\mathrm{cm} / \mathrm{cm})$ value relating the Van Genuchten parameters (n and $\alpha$ ) for a certain soil type to the infiltration water suction $\left(\mathrm{h}_{0}\right)$ and the 
infiltrometer disk radius $(2.25 \mathrm{~cm})$. A is computed from equations (3) and (4):

$\mathrm{A}=\frac{11.65\left(n^{0.1}-1\right) \exp \left[2.92(n-1.9) \alpha h_{0}\right]}{\left(\alpha r_{0}\right)^{0.91}} \mathrm{n} \geq 1.9$

$\mathrm{A}=\frac{11.65\left(n^{0.1}-1\right) \exp \left[7.5(n-1.9) \alpha h_{0}\right]}{\left(\alpha r_{0}\right)^{0.91}} \quad \mathrm{n} \leq 1.9$

where $\mathrm{n}$ and $\alpha$ are the van Genuchten parameters for the soil, $\mathrm{r}_{\mathrm{o}}$ is the disk radius, and ho is the suction at the disk surface. In this study, $\mathrm{h}_{0}$ is equal to $-2 \mathrm{~cm}$.

The calibration program-RETC was used to describe the soil hydraulic functions (Yates et al., 1992). The results are shown in Table 2. The soil hydraulic data of the water repellent and wettable soil only differ in the hydraulic conductivity of the top layer. RETC uses the Brooks and Corey (1964), Van Genuchten and Nielson (1985), Burdine (1953) or Mualem (1976) relationships for describing the waterretention curve and predictive models for characterizing the unsaturated hydraulic conductivity (Yates et al., 1992).

In the field, a measurement was performed when the soil was dry and water repellent. However, in the laboratory, before measuring the retention function and the hydraulic conductivity, soil samples were saturated. Also, the soil samples relatively long equilibrium time are allowed. This condition removed soil water repellency.

\subsection{Rainfall simulation experiment}

Rainfall simulators are an important device in erosion and infiltration research. The primary purpose of a rainfall simulator is to simulate natural rainfall accurately and precisely. In this study, an indoor nozzletype rainfall simulator (RS) was used to assess rainfall infiltration and runoff. The rainfall simulator is a pressurized nozzle type simulator. The device is equipped with 4 Lechler nozzles (two nr. 460,788 and two nr. 461,008).

Water is supplied from the basin in the basement of the hydraulic lab. Water pressure in the system is $2-2.5$ bar $(2000-2500 \mathrm{hPa})$. Control at the manometer on the pump can be regulated with a plug valve on the bypass. The RS consists of a $6 \mathrm{~m}$ long and $2.5 \mathrm{~m}$ wide plot, with a $2.8 \mathrm{~m}$ high metal lateral frame and one open side down the slope (Fig. 1). The bottom is freely drained and subdivided into 6 segments. The rainfall simulator is described in detail by Lassu et al. (2015).

The rainfall intensity was determined by the amount of water collected (measured with gauges) during an experiment. After each repetition, the gauges were collected and the average rainfall intensity was calculated. Rain uniformity was determined using the Christiansen coefficient. The Christiansen uniformity coefficient (CU) is used to determine the spatial heterogeneity or homogeneity of a certain rainfall event (Christiansen, 1942). It was calculated from the collected data for the different flow rates and for each repetition. The value of uniformity coefficient was obtained using the following equation between 70 and $72 \%$

$C U=100 \%\left[1-\frac{\sum_{i=1}^{n} \mid x_{i-} \bar{x}}{\bar{x}-n}\right]$

CU is the Christian uniformity coefficient, $x_{i}$ the individual water amount per rain gauge $[\mathrm{ml}], \bar{x}$ the arithmetic mean of applied water amount per rain gauge $[\mathrm{ml}]$

Twenty-seven intact dry topsoil samples with a thickness of $20 \mathrm{~cm}$ were collected from the study site on September 10, 2017. The reason for choosing this time is that at this time, the main parts of the soil profile down to $40 \mathrm{~cm}$ were completely dry and repellent. This is also the time that heavy rains occur in the area. Soil samples, maintaining a bulk density ( $\rho s)$ similar to the natural one, were placed in boxes $35 \mathrm{~cm}$ long, $25 \mathrm{~cm}$ wide, and $20 \mathrm{~cm}$ deep. Three ranges of soil water content $(\theta<2 \%, \theta=4 \%$ and $>14)$ were selected according to the soil water content at different times of the simulated period (Fig. 3).

According to the frequency of rain intensity during the measurement period based on the weather station information, three rainfall intensities of 14, 27 and $34 \mathrm{~mm} \cdot \mathrm{h}^{-1}$ were applied. All measurements were performed for $15 \mathrm{~min}$ on three occasions (Lassu et al., 2015). Runoff was collected in plastic bottles and runoff was calculated per unit area. In this study, we were interested in surface runoff as a result of intensive rainfall.

\subsection{Soil evaporation}

To investigate the impact of soil water repellency on evaporation, four cylinders ( $50 \mathrm{~mm}$ inner diameter $\times 65 \mathrm{~mm}$ height) were filled with wettable sandy soil (sieved at $2 \mathrm{~mm}$ ). Soil samples were wetted from the bottom for $24 \mathrm{~h}$ then $2-\mathrm{cm}$ thick layers of water repellent soil were placed on the surface of each cylinder. A plastic ring was used to contain the repellent layer. The samples were placed in laboratory conditions at $25 \pm 1{ }^{\circ} \mathrm{C}$ and a relative air humidity of $50 \%$. Finally, water evaporation from soil samples was determined from the loss of weight in a temperature-controlled laboratory condition (Lichner et al., 2020).

\subsection{Model framework}

The SWAP. 4 model simulates the transport of water, solutes and heat in the vadose zone in interaction with vegetation development. The model domain reaches from a plane just above the canopy to a plane at the groundwater level or at a certain depth in the vadose zone. In this region, the transport processes are predominantly vertical. Therefore, the SWAP model is a one-dimensional, vertically directed model. The model employs the Richards equation including root water extraction to simulate soil moisture water movement in soils. Soil moisture condition was determined based on pressure head as a function of soil depth (Kroes et al., 2017).

\subsection{The model boundary conditions}

\subsubsection{Top boundary conditions}

The upper boundary conditions are determined by the rates of potential evapotranspiration (transpiration plus evaporation flux), rainfall or irrigation, and the soil vegetation properties (Van Dam and Feddes, 2000). Daily meteorological data, consisting of air temperature, solar radiation, wind speed, and air humidity, can be used to calculate daily potential evapotranspiration according to the Penman-Monteith method (Allen et al., 1998).

\subsubsection{Bottom boundary conditions}

At the bottom, various forms of head and flux-based conditions are used. In this study due to the deep groundwater, free drainage was used (Kramers et al., 2005). In the case of free drainage, the hydraulic head gradient is assumed to be equal to one at the bottom boundary, which sets the bottom flux $q_{\text {bot }}$ equal to the hydraulic conductivity of the lowest compartment:

$\frac{\partial H}{\partial Z}=1 \quad$ thus $\quad \mathrm{q}_{\mathrm{bot}}=-\mathrm{K}_{\mathrm{n}}$

$\frac{\partial H}{\partial Z}$ : Total hydraulic head, $\mathrm{q}_{\text {bot }}$ : bottom flux, $\mathrm{K}_{\mathrm{n}}$ : hydraulic conductivity of lowest component.

In the field experiments condition, with deep water table levels, initial soil moisture condition is determined by the pressure head as a function of soil depth with linear interpolation between depths (Kroes et al., 2017).

\subsubsection{Simulation of water movement in soils}

Basically, within SWAP, soil water flow is calculated using the Darcy and conservation of mass equation (Richard equation). Water moves in 


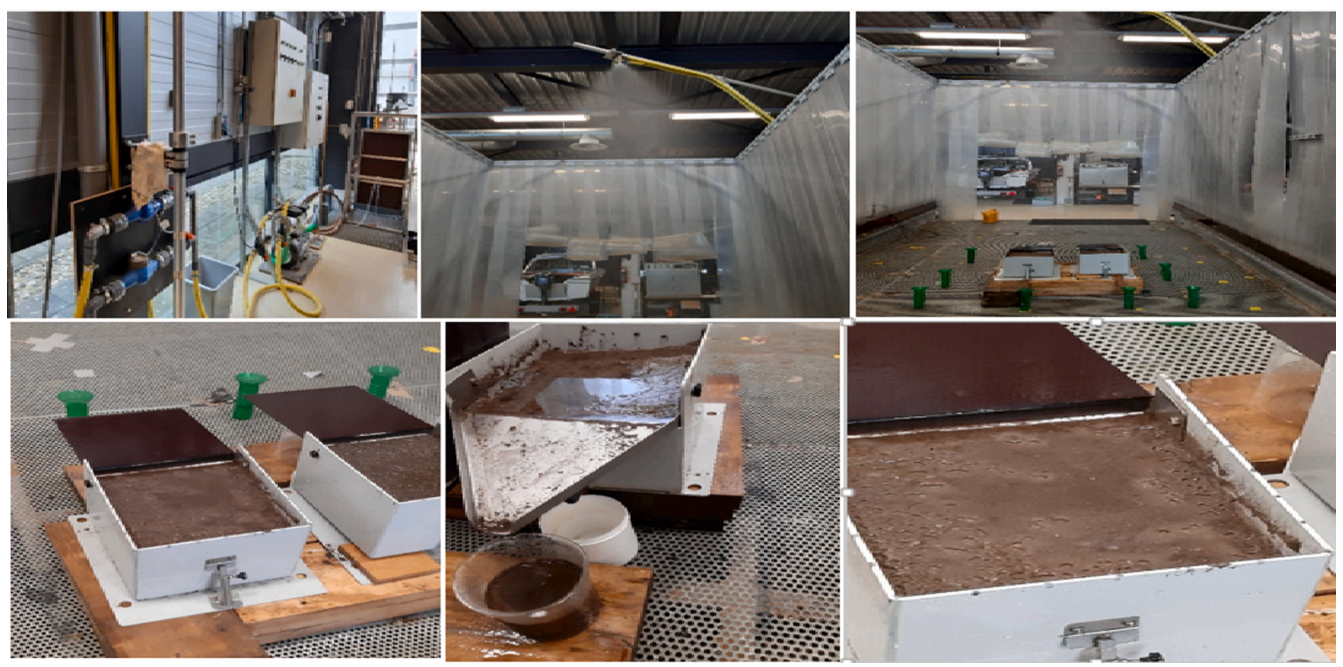

Fig.3. Photographs of the runoff measurement using an indoor nozzle-type rainfall simulator (RS).

the soil due to the gradient of the soil water potential.

$\frac{\partial \hat{\mathrm{I}}_{s}}{\partial \mathrm{t}}=\frac{\partial\left[\mathrm{K}(\mathrm{h})\left(\frac{\partial \mathrm{h}}{\partial \mathrm{z}}+1\right)\right]}{\partial \mathrm{z}}-\mathrm{Sa}(\mathrm{h})-\mathrm{Sd}(\mathrm{h})-\mathrm{Sm}(\mathrm{h})$

where $\theta$ is volumetric water content $\left(\mathrm{cm}^{3} \cdot \mathrm{m}^{-3}\right), \mathrm{t}$ is time $(\mathrm{d}), \mathrm{K}(\mathrm{h})$ is hydraulic conductivity $\left(\mathrm{cm} \cdot \mathrm{d}^{-1}\right), \mathrm{h}$ is soil water pressure head $(\mathrm{cm})$ and $\mathrm{z}$ is the vertical coordinate $(\mathrm{cm}), S_{a}(\mathrm{~h})$ is soil water extraction rate by plant roots $\left(\mathrm{cm}^{3} \mathrm{~cm}^{-3} \mathrm{~d}^{-1}\right), S_{d}(\mathrm{~h})$ is the extraction rate by drain discharge in the saturated zone $\left(\mathrm{cm}^{3} \mathrm{~cm}^{-3} \mathrm{~d}^{-1}\right)$ and $S_{m}(\mathrm{~h})$ is the exchange rate with macropores $\left(\mathrm{cm}^{3} \mathrm{~cm}^{-3} \mathrm{~d}^{-1}\right)$.

SWAP applies the Richards equation integrally for the unsaturatedsaturated zone. The Richards equation is solved using a numerical implicit, backward, finite difference scheme with explicit linearization of hydraulic conductivities (Van Dam and Feddes, 2000; Van Dam et al., 2008). The numerical solution of Eq (7) requires specified boundary conditions and relations between $\theta, \mathrm{h}$ and $\mathrm{K}$, the so-called soil hydraulic functions. For these functions, SWAP uses the Mualem-Van Genuchten analytical equations (Mualem, 1976; van Genuchten, 1980) which have been used in numerous studies and form the base of several national and international database (Vereecken et al., 2010).

The analytical $\theta(h)$ function proposed by van Genuchten (1980) is defined as:

$\theta(h)=\theta$ res $+(\theta$ sat - - $r e s)(1+|\alpha h| \mathrm{n})-\mathrm{m}$

where $\theta$ sat is the saturated water content $\left(\mathrm{cm}^{3} \mathrm{~cm}^{-3}\right), \theta$ res is the residual water content in the very dry range $\left(\mathrm{cm}^{3} \mathrm{~cm}^{-3}\right)$ and $\alpha\left(\mathrm{cm}^{-1}\right), \mathrm{n}(-)$ and $\mathrm{m}(-)$ are empirical shape factors. Without losing much flexibility, $\mathrm{m}$ could be taken equal to:

$m=1-\frac{1}{n}$

Using the above $\theta(h)$ relation, with $\mathrm{m}=1-\frac{1}{\mathrm{n}}$, and applying the theory on unsaturated hydraulic conductivity by Mualem (1976), the following $k(\theta)$ function results:

$\mathrm{K}=\mathrm{K}_{\mathrm{sat}} S_{e}^{\lambda}\left[1-\left(1-S_{e}^{\frac{1}{m}}\right)^{m}\right]^{2}$

where $K_{\text {sat }}$ is the saturated conductivity $\left(\mathrm{cm} \cdot \mathrm{d}^{-1}\right), \lambda$ is a shape parameter $(-)$ depending on flow path tortuosity, and $S_{e}$ is the relative degree of saturation defined as:

$S_{e}=\frac{\theta-\theta_{\text {res }}}{\theta_{\text {sat }}-\theta_{\text {res }}}$

where $\theta$ is volumetric water content $\left(\mathrm{cm}^{3} \cdot \mathrm{m}^{-3}\right), \mathrm{t}$ is time (d), $\mathrm{K}(\mathrm{h})$ is hydraulic conductivity $\left(\mathrm{cm} \cdot \mathrm{d}^{-1}\right), \mathrm{h}$ is soil water pressure head $(\mathrm{cm})$ and $\mathrm{z}$ is the vertical coordinate $(\mathrm{cm}), S_{a}(\mathrm{~h})$ is soil water extraction rate by plant roots $\left(\mathrm{cm}^{3} \mathrm{~cm}^{-3} \mathrm{~d}^{-1}\right), S_{d}(\mathrm{~h})$ is the extraction rate by drain discharge in the saturated zone $\left(\mathrm{cm}^{3} \mathrm{~cm}^{-3} \mathrm{~d}^{-1}\right)$ and $S_{m}(\mathrm{~h})$ is the exchange rate with macropores $\left(\mathrm{cm}^{3} \mathrm{~cm}^{-3} \mathrm{~d}^{-1}\right)$.

\subsubsection{Water movement in repellent soil}

In general, the SWAP model calculates uniform flow as described above. Field observations show soil water flows in preferred pathways (finger flow) and only a part of the soil matrix actively participates in the flow process. Thus, uniform flow was not appropriate for this soil. Therefore, SWAP 4.0 was adapted to correctly simulate the soil water balance and runoff for repellent sandy soil. The implemented concept is described below.

In the laboratory, the samples were first brought to saturation and long equilibrium times were allowed. In measured water retention functions, effects of repellency are less or absent. It is assumed that water retention $\theta(\mathrm{h})$ and hydraulic conductivity $\mathrm{K}(\mathrm{h})$, as measured in the laboratory, are valid only for parts through which water flows (the wettable, mobile region). In field conditions, the soil may be water repellent, in which case the bulk soil consists of mobile and immobile parts. Transient flow conditions apply to a fraction of the volume of soil in which water is mobile ( $\left.\mathrm{F}_{\mathrm{mob}}\right)$. In repellent parts, only immobile water is considered. Therefore, the average mobile amount of initial water content is $\mathrm{F}_{\mathrm{mob}}$ times smaller than in wettable soil. A second assumption is that the water content in the immobile region (water repellent, finger region) is constant. The fraction of wettable regions is determined by the reduction factor $\mathrm{F}$ and the fraction of the water-repellent region by ( 1 F). To simulate water flow in water repellent soils, SWAP applies the Richards' equation only to the mobile region. Thus, the effective retention function, which is used to solve the Richards equation, is related to laboratory measurement $\theta^{l a b}(h)$ as follows:

$\theta(h)=F_{m o b} \theta^{l a b}(\mathrm{~h})$

where $\mathrm{F}_{\mathrm{mob}}$ : the volumetric of the soil was occupied by preferential flow and equal to the mobile fraction of the soil volume. Similarly, the field hydraulic conductivity function $K(h)$ which should be used in the solution of Richards' equation, is related to $\mathrm{K}_{\mathrm{lab}}(\mathrm{h})$ measured in the laboratory as:

$\mathrm{K}(\mathrm{h})=F_{m o b} K^{l a b}(h)$

The SWAP model assumes the individual soil layers to be homogenous horizontally. The volume of preferential flow paths is relatively stable during a season, therefore during a season, $\mathrm{F}_{\mathrm{mob}}$ is assumed to be 
constant. The $\mathrm{F}_{\mathrm{mob}}$ factor can be estimated using visual observation in the field with the tracer color test (Brilliant Blue). Field studies show that the mobile fraction $\mathrm{F}_{\mathrm{mob}}$ changes between seasons (Ritsema and Dekker, 1994). Also, the $F_{m o b}$ parameter changes by increasing the depth so we define the value of the F parameter at each depth and each season. When the soil becomes wetter, $F_{m o b}$ increases. Therefore in winter, when the soil is wet, the parameter is considered to be one.

\section{Results}

\subsection{Characterization of soils and numerical simulation of water content}

In this study, a water repellent sandy soil texture was selected because water repellency occurs most frequently in these soils (Ritsema et al., 2005). Furthermore, coniferous forest soils are more prone to soil water repellency than deciduous forest soils (Butzen et al., 2015). Some of the soil properties of different layers are shown in Table 1.

Soil hydraulic data in conditions where the soils are water repellent and wettable is given in Table 2 . The results showed that the hydraulic conductivity measured in the laboratory was greater than in field conditions because in the field, the flow is limited to the fingers. Also, the measurement of hydraulic conductivity of intact samples in the laboratory using the Mini dis infiltrometer showed that the unsaturated hydraulic conductivity measured in wettable samples was higher than in repellent samples (Table 2 ).

The average variations of soil water repellency (WDPT) from August 2017 to July 2018 are listed for different depths in Table 3. Due to the seasonal changes in soil water repellency, the model simulation was divided into three periods. In the first period (August to October 2017), the average soil water repellency (WDPT test) in the upper $15 \mathrm{~cm}$ was $2500 \mathrm{~s}$, at $15-40 \mathrm{~cm}$ it was $80 \mathrm{~s}$, and deeper in the profile $(40-250 \mathrm{~cm})$ soils were wettable.

In the second period (November to April 2018), soils were wettable at all depths. In the third period (May-July 2018), the soils were repellent to a depth of $40 \mathrm{~cm}$ (Table 3). To demonstrate the effect of water repellency, simulations were performed with a constant mobile fraction $\left(F_{\text {mob }}\right)$ for every depth for each period (Table 3$)$. We assumed that the repellency degree in each layer was uniform and therefore, the repellency of each layer was determined by one value of the $\mathrm{F}_{\text {mob }}$ parameter.

The simulated and measured soil water content at depths of $0-15 \mathrm{~cm}$, $15-40 \mathrm{~cm}$ and $40-250 \mathrm{~cm}$ are shown in Fig. 4. Two simulations were considered, one location which was water repellent / wettable soil, depending on the season (simulation 1 ) and one for a location which was continuously wettable (simulation 2). The simulations started with the same initial water content on August 1st and then the simulated water contents at the end of the former period were considered as the initial water conditions for the next period. In the case of simulation 1 , soil water repellency was considered using the $\mathrm{F}_{\text {mob }}$ parameter, but in simulation 2, soils were considered to be wettable. Measurement of soil water content in the periods showed that by entering the repellency parameter $\left(\mathrm{F}_{\mathrm{mob}}\right)$ in the model, the SWAP model could effectively simulate the correct soil water content.

The average volumetric water content measured at various depths, estimated by simulation 1 (considering water repellency) and simulation 2 (assuming the wettable soil) is given in Table 4, these values are also shown in more detail in Fig. 4.

\section{Table 1}

Soil properties at three soil depths: acidity $(\mathrm{pH})$, electrical conductivity (EC), organic matter $(\mathrm{OM})$, soil texture, and dry bulk density $\left(\rho_{\mathrm{b}}\right)$.

\begin{tabular}{llllllll}
\hline $\begin{array}{l}\text { Depth } \\
(\mathrm{cm})\end{array}$ & $\mathrm{pH}$ & $\begin{array}{l}\mathrm{EC} \\
(\mathrm{ds} \cdot \mathrm{m})\end{array}$ & $\begin{array}{l}\text { OM } \\
(\%)\end{array}$ & $\begin{array}{l}\text { Sand } \\
(\%)\end{array}$ & $\begin{array}{l}\text { Silt } \\
(\%)\end{array}$ & $\begin{array}{l}\text { Clay } \\
(\%)\end{array}$ & $\begin{array}{l}\rho_{b} \\
\left(\mathrm{~g} \cdot \mathrm{cm}^{-1}\right)\end{array}$ \\
\hline $0-15$ & 7.02 & 0.13 & 7.82 & 92.0 & 4.0 & 4.0 & 1.12 \\
$15-40$ & 7.1 & 0.1 & 1.05 & 93.0 & 4.0 & 3.0 & 1.22 \\
$40-250$ & 7.12 & 0.07 & 0.08 & 93.5 & 4.0 & 2.5 & 1.25 \\
\hline
\end{tabular}

Table 2

The soil hydraulic parameters determined in the laboratory on samples from 0 to $15,15-40$, and $40-250 \mathrm{~cm}$ depth $(\mathrm{n}=3)$. Soil hydraulic conductivity value $(\mathrm{K})$ was calculated according to Dohnal et al. (2010); subscript MD stands for mini disc infiltrometer.

\begin{tabular}{|c|c|c|c|c|c|c|}
\hline & \multicolumn{3}{|c|}{ Water repellent soil } & \multicolumn{3}{|c|}{ Wettable soil } \\
\hline & $\begin{array}{l}0-15 \\
\mathrm{~cm}\end{array}$ & $\begin{array}{l}15-40 \\
\mathrm{~cm}\end{array}$ & $\begin{array}{l}40-250 \\
\mathrm{~cm}\end{array}$ & $\begin{array}{l}0-15 \\
\mathrm{~cm}\end{array}$ & $\begin{array}{l}15-40 \\
\mathrm{~cm}\end{array}$ & $\begin{array}{l}40-250 \\
\mathrm{~cm}\end{array}$ \\
\hline$\theta_{\text {sat }}(-)$ & 0.3 & 0.25 & 0.2 & 0.3 & 0.25 & 0.2 \\
\hline$\theta_{\text {res }}(-)$ & 0.01 & 0.01 & 0.01 & 0.01 & 0.01 & 0.01 \\
\hline $\begin{array}{l}\mathrm{K}_{\mathrm{MD}}, \mathrm{h}= \\
-2 \mathrm{~cm}(\mathrm{~cm} \\
\left.\mathrm{d}^{-1}\right)\end{array}$ & 63 & 223.0 & 280 & 223 & 253.0 & 280 \\
\hline$\alpha\left(\mathrm{cm}^{-1}\right)$ & 0.04 & 0.039 & 0.039 & 0.045 & 0.039 & 0.039 \\
\hline $1(-)$ & 0.5 & 0.5 & 0.5 & 0.5 & 0.5 & 0.5 \\
\hline n (-) & 2.24 & 2.29 & 2.65 & 2.24 & 2.29 & 2.65 \\
\hline
\end{tabular}

From the beginning of August to the end of October (period 1), the soils were completely repellent and an overestimation was observed in the soil water simulated by the model using laboratory data based on wettable soil. The average volumetric water content of the topsoil (0-15 $\mathrm{cm}$ ) was measured between $1.2 \%$ and $4.34 \%$ (Fig. 4.a). The average volumetric water content estimated by simulation 1 (considering water repellency) was between $3.12 \%-5.7 \%$, while simulation 2 (assuming the wettable soil) estimated the value of $15.5 \%-26.8 \%$ for this parameter. The results showed that from August to October 2017 (period 1) and April-July 2018 (period 3), simulation 2 (assuming the wettable soil) overestimated the soil water content in the topsoil $(0-15 \mathrm{~cm})$ (Fig. 4a).

Obviously, the middle of the profile $(15-40 \mathrm{~cm})$ has less water content as compared to the top layers (Fig. 4.b, Table 4). Although in the case of water repellency (simulation 1), the model has been able to simulate the amount of soil water content closer and more accurately to the measured value. At this depth, there is no obvious overestimation such as those for the top layer $(0-15 \mathrm{~cm})$. This could be due to the reduction of soil water repellency at this depth (Table 2). This trend was observed in both period 1 and period 3 at this depth (15-40) (Fig. 4b). During period 2 (November to April), the soils were completely wettable and a value of one was considered for the $F_{\text {mob }}$ parameter. This means that water flowed through the entire volume of soil. The amount of volumetric water content of the topsoil $(0-15 \mathrm{~cm})$ and the second layer $(15-40 \mathrm{~cm})$ were estimated to be the same by both simulations.

The variation in soil water content measured in the deeper part $(40-250 \mathrm{~cm})$ of the profile was less than $5 \%$. At this depth, the soil was completely wettable throughout the simulation period, leading to homogenous flow and it is expected that there was no difference between the results of simulation 1 and simulation 2 but that an overestimation of the amount of soil water content was observed in simulation 2 from October 13th to the end of February (Fig. 4c). However, the initial water content on November 1st was different in the simulation in the case of the water repellent (simulation 1) and wettable soil (simulation 2). From November to April, the second simulation (without considering water repellency) showed an overestimation in the amount of soil water content at a depth of $45-250 \mathrm{~cm}$ but there was no difference in the amount of soil water content from November to April in both simulations at depths of $0-15$ and $15-45 \mathrm{~cm}$.

Although the range of changes in soil water content in simulation 2 was higher than in simulation 1 (Table 4), Fig. 4C shows that from August 31st to October 11th (period 1) the amount of soil water content in simulation 1 (with water repellency) was somewhat higher than in simulation 2. However, the result of simulation 1 was correct and closer to the measured data. In total, from the end of October until April, during the winter, the wettest situation was observed at every depth. 
Table 3

The variation in water repellency and F parameter at different depths, during three sampling periods.

\begin{tabular}{|c|c|c|c|c|c|c|c|c|c|}
\hline & \multicolumn{3}{|c|}{ Aug-Oct 2017} & \multicolumn{3}{|c|}{ Nov-Apr 2018} & \multicolumn{3}{|c|}{ May-Jul 2018} \\
\hline & $0-15 \mathrm{~cm}$ & $15-40 \mathrm{~cm}$ & $40-250 \mathrm{~cm}$ & $0-15 \mathrm{~cm}$ & $15-40 \mathrm{~cm}$ & $40-250 \mathrm{~cm}$ & $0-15 \mathrm{~cm}$ & $15-40 \mathrm{~cm}$ & $40-250 \mathrm{~cm}$ \\
\hline WDPT (s) & 2500 & 80 & 0 & 0 & 0 & 0 & 650 & 45 & 0 \\
\hline F & 0.5 & 0.7 & 1 & 1 & 1 & 1 & 0.6 & 0.8 & 1 \\
\hline
\end{tabular}

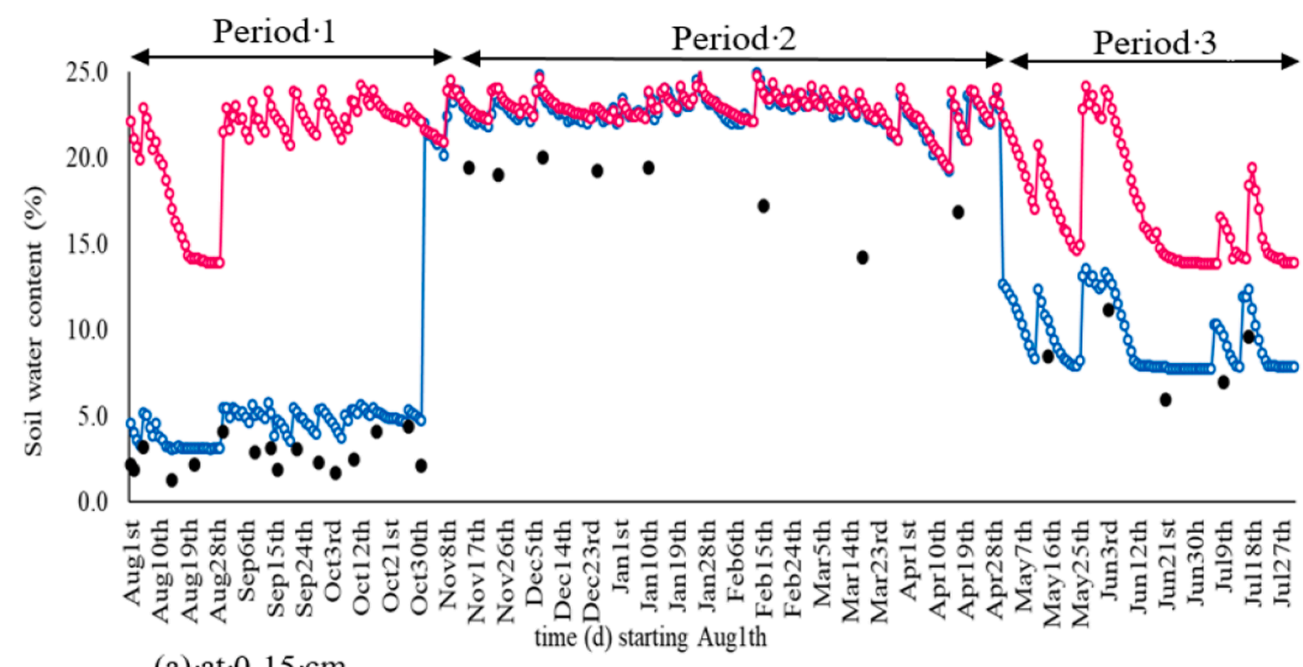

(a) at $\cdot 0-15 \cdot \mathrm{cm} \rightarrow$ - Simulated $1 \rightarrow$ - Simulated $2 \rightarrow$ Measured
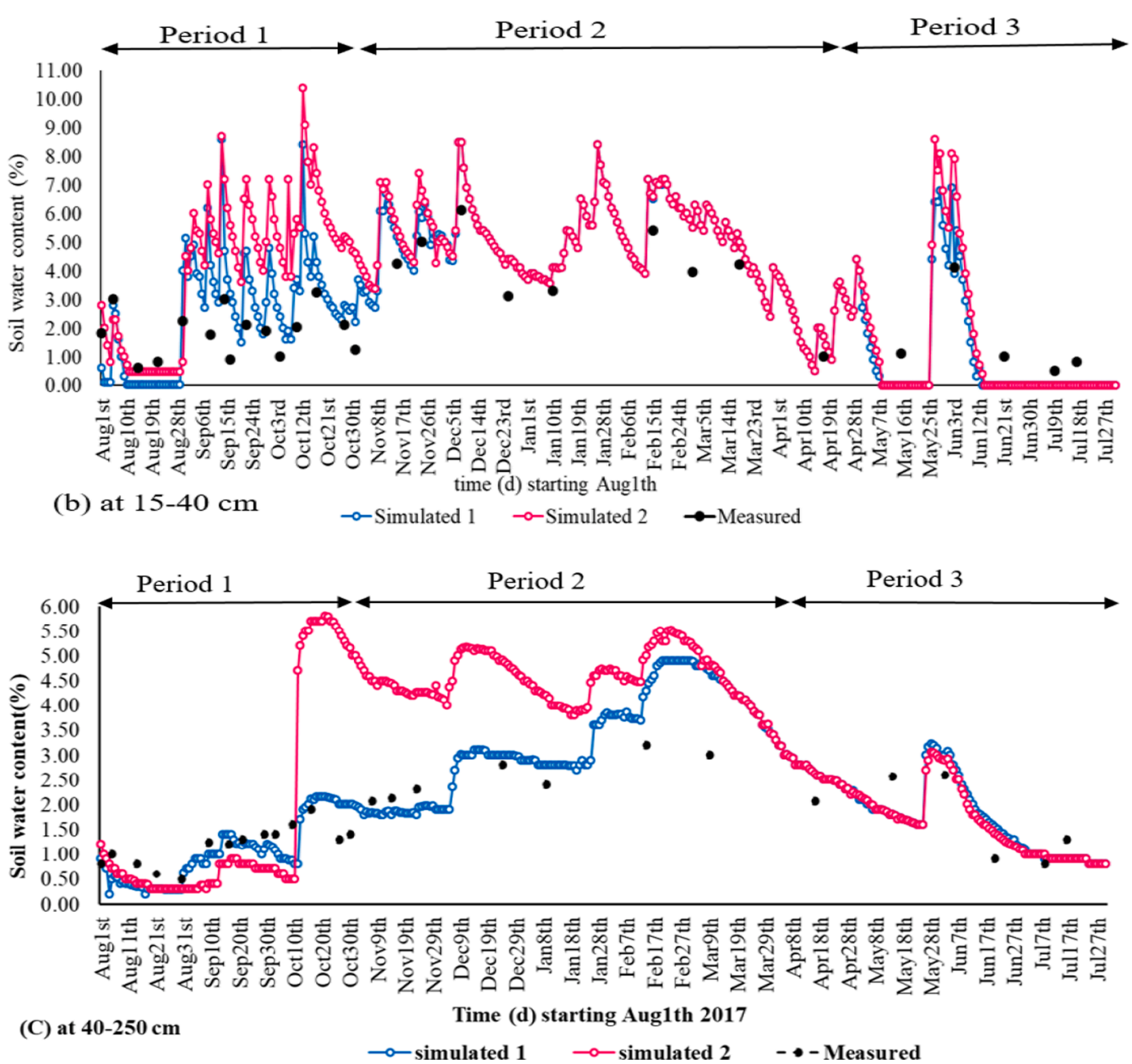

Fig 4. The average of Measured and Simulated 1 (with considering water repellency), simulated 2 (without considering water repellency) soil water content (a) at 0-15 cm (b) $15-40 \mathrm{~cm}$ and (c) $40-250 \mathrm{~cm}$ using the adapted SWAP. 4 model. 
Table 4

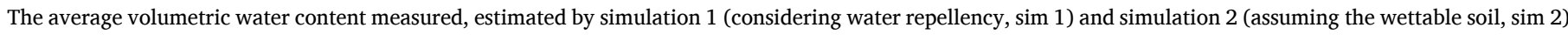
at three depths and during three simulation periods.

\begin{tabular}{|c|c|c|c|c|c|c|c|c|c|}
\hline & \multicolumn{3}{|l|}{$0-15 \mathrm{~cm}$} & \multicolumn{3}{|l|}{$15-40$} & \multicolumn{3}{|l|}{$40-250 \mathrm{~cm}$} \\
\hline & Measured & Sim 1 & Sim 2 & Measured & $\operatorname{Sim} 1$ & Sim 2 & Measured & Sim 1 & $\operatorname{Sim} 2$ \\
\hline Aug-Oct & $1.2-4.34$ & $3.1-5.7$ & $15.5-26.8$ & $0.8-3$ & $0.2-7.0$ & $0.6-10$ & $0.5-1.9$ & $0.2-2.1$ & $0.3-5.8$ \\
\hline Nov-Mar & $14.2-20$ & $23.3-27.4$ & $23.3-27.4$ & $3-5.75$ & $2.8-7.8$ & $2.7-7.5$ & $2.07-3.2$ & $1.0-4.2$ & $3.6-5.5$ \\
\hline Apr-Jul & $5.9-16.8$ & $7-26.7$ & $15.4-26.7$ & $0.3-3.6$ & $0.2-6$ & $0.2-8$ & $0.8-2.6$ & $0.8-3.4$ & $0.8-5.3$ \\
\hline
\end{tabular}

\subsection{Water balance and runoff}

The simulated water balances are shown in Table 5 for all three periods. The negative value of soil water flux at the bottom represents downward flow (deep percolation) of water while positive fluxes represent upward flow (capillary rise). Due to the deep groundwater level, upward flow did not occur in the experimental site. Therefore, throughout the simulated periods, the water fluxes at the bottom of the soil profile are downward (Table 5).

Since the simulation was performed in three continuous periods, it was expected that the final water storage of each period was equal to the initial water storage of the next period. This is seen in the results of the SWAP when the water repellency is ignored (simulation 2).

In simulation 2, the final water storage of the first period (August to October) was $15.64 \mathrm{~cm}$, and the same value was given as the initial water storage of the second period (November to April). The final water storage in the second period was 9.63 and the amount of the initial water in the third period (May to July) was the same. In the case that considered water repellency by entering the $F_{\text {mob }}$ parameter into the model, the final water storage of the first period (August to October) was $5.59 \mathrm{~cm}$, but the initial water storage of the second period (November to April) had increased to $8.97 \mathrm{~cm}$. The final water storage in the second period was $9.64 \mathrm{~cm}$ but the amount of the initial water in the third period (May to July) had decreased to $7.48 \mathrm{~cm}$.

As the simulation results show, considering water repellency, there was runoff in the first (August to October) and third (May to July) periods. However, during the second period (November to April) soil was completely wettable and the $\mathrm{F}$ parameter was considered to be one (Table 3). This $(F=1)$ means the whole soil was active in the movement of water in the soil. The amount and dates of runoff simulated by the model during the experimental period are given in more detail in Table 6. Measured and simulated soil water contents showed that the soils were dry and water repellent at the runoff dates.

The frequency of rain intensity during the simulation period is shown in Fig. 5. The highest rainfall amount was measured in October with a rain intensity of $46.2 \mathrm{~mm} \cdot \mathrm{h}^{-1}$. Also in September and May, high rain intensities were measured between 20 and $40 \mathrm{~mm} \cdot \mathrm{h}^{-1}$ (Fig. 5).

To validate the simulated runoff by the model, rain experiments were performed under laboratory conditions. Rainfall simulators have been
Table 6

The amount of rain $(\mathrm{mm})$, maximum rain intensity $\left(\mathrm{mm} \cdot \mathrm{h}^{-1}\right)$, water content, water repellency on days with runoff.

\begin{tabular}{ccllll}
\hline Date & $\begin{array}{l}\text { Rain } \\
(\mathrm{mm})\end{array}$ & $\begin{array}{l}\text { Max Rain } \\
\text { intensity } \\
\left(\mathrm{mm} \mathrm{h}^{-1}\right)\end{array}$ & $\begin{array}{l}\text { Water } \\
\text { content } \\
\text { before }\end{array}$ & $\begin{array}{l}\text { Water } \\
\text { repellency } \\
(\text { mean })\end{array}$ & $\begin{array}{l}\text { Runoff } \\
(\mathrm{mm}) \\
\text { measured }\end{array}$ \\
\hline $\begin{array}{c}\text { Sep } \\
\text { 13th }\end{array}$ & 26.8 & 35.6 & $1-5 \%$ & 1280 & 3.17 \\
2017 & & & & & \\
$\begin{array}{c}\text { Oct } \\
\text { 12th }\end{array}$ & 112.5 & 46.2 & $1-5 \%$ & 1320 & 80.9 \\
2017 & & & $2-7 \%$ & 250 & 7.4 \\
$\begin{array}{c}\text { May } \\
\text { 26th }\end{array}$ & 32.5 & 40.8 & & & \\
2018 & & & & & \\
\hline
\end{tabular}

used extensively to collect runoff, infiltration, and erosion data in both laboratory and field experiments. Rainfall intensity was selected based on field observations and meteorological station information.

Therefore, the amount of runoff generated at three rainfall intensities $\left(14,27\right.$ and $34 \mathrm{~mm} \cdot \mathrm{h}^{-1}$ ) and under three soil moisture conditions observed in the area was measured in laboratory conditions (Table 7).

The laboratory data show that rain with an intensity of more than 27 $\mathrm{mm} \cdot \mathrm{h}^{-1}$ creates runoff when the soil moisture is less than $2 \%$ and the soil is extremely repellent. When the soil water content is about $4 \%$, slight water repellency is observed. Under these conditions, only rains with an intensity of $34 \mathrm{~mm} \cdot \mathrm{h}^{-1}$ and more produce runoff. By increasing the amount of soil moisture (14-40\%), soils become completely wettable. Under these conditions, no runoff was observed even at a rainfall intensity of $34 \mathrm{~mm} \cdot \mathrm{h}^{-1}$ (Table 7 ).

The amount of rain and the duration of each rain event are given in Figs. 6, 7 and 8. Also, the runoff simulated by the SWAP model is given in each graph. During periods from August to October 2017, the soil water content was between 1.2 and 4.07. At this time of year, the soils are completely repellent. (Table 3 ).

The results of the model show that the rain of September 13th, with a duration of 0.07 days, caused runoff $(3.17 \mathrm{~mm})$. Heavy rainfall occurred on October 12th, in which $112.5 \mathrm{~mm}$ of rainfall fell within 0.413 days. This extreme rainfall event caused the largest amount of runoff, equal to $80.9 \mathrm{~mm}$.

Table 5

Simulated water balance components and runoff from August 2017 until July 2018.

\begin{tabular}{|c|c|c|c|c|c|c|}
\hline \multirow{2}{*}{$\begin{array}{l}\text { Water balance components } \\
(\mathrm{cm})\end{array}$} & \multicolumn{3}{|c|}{ Simulated with water repellency } & \multicolumn{3}{|c|}{ Simulated without water repellency } \\
\hline & $\begin{array}{l}\text { Aug 01st-Oct 31st } \\
2017\end{array}$ & $\begin{array}{l}\text { Nov 01st-Apr 30th } \\
\text { 2017-2018 }\end{array}$ & $\begin{array}{l}\text { May 01st-Jul 31st } \\
2018\end{array}$ & $\begin{array}{l}\text { Aug 01st-Oct 31st } \\
2017\end{array}$ & $\begin{array}{l}\text { Nov 01st-Apr } \\
\text { 30th }\end{array}$ & $\begin{array}{l}\text { May 01st-Jul } \\
\text { 31st }\end{array}$ \\
\hline Rain & 30.81 & 29.56 & 14.55 & 30.81 & 29.56 & 14.55 \\
\hline Potential transpiration & 28.06 & 20.67 & 42.41 & 28.06 & 20.67 & 42.41 \\
\hline Actual transpiration & 14.56 & 19.05 & 14.32 & 15.8 & 19.08 & 15.59 \\
\hline Potential evaporation & 1.22 & 0.90 & 1.84 & 1.22 & 0.9 & 1.84 \\
\hline Actual evaporation & 0.69 & 0.9 & 0.83 & 1.04 & 0.9 & 1.31 \\
\hline Runoff & 8.41 & 0.0 & 0.75 & 0.00 & 0.0 & 0.0 \\
\hline interception & 4.89 & 6.84 & 2.59 & 4.89 & 6.84 & 2.59 \\
\hline Bottom Flux (-, downward) & -0.01 & -2.11 & -0.6 & -1.13 & -8.75 & -0.6 \\
\hline Final water storage & 5.59 & 9.64 & 2.94 & 15.64 & 9.63 & 4.10 \\
\hline Initial water storage & 3.33 & 8.97 & 7.48 & 7.68 & 15.64 & 9.63 \\
\hline Change storage (top $250 \mathrm{~cm}$ ) & 2.26 & 0.67 & -4.54 & 7.96 & -6.01 & -5.53 \\
\hline
\end{tabular}


Rain intensity distribution

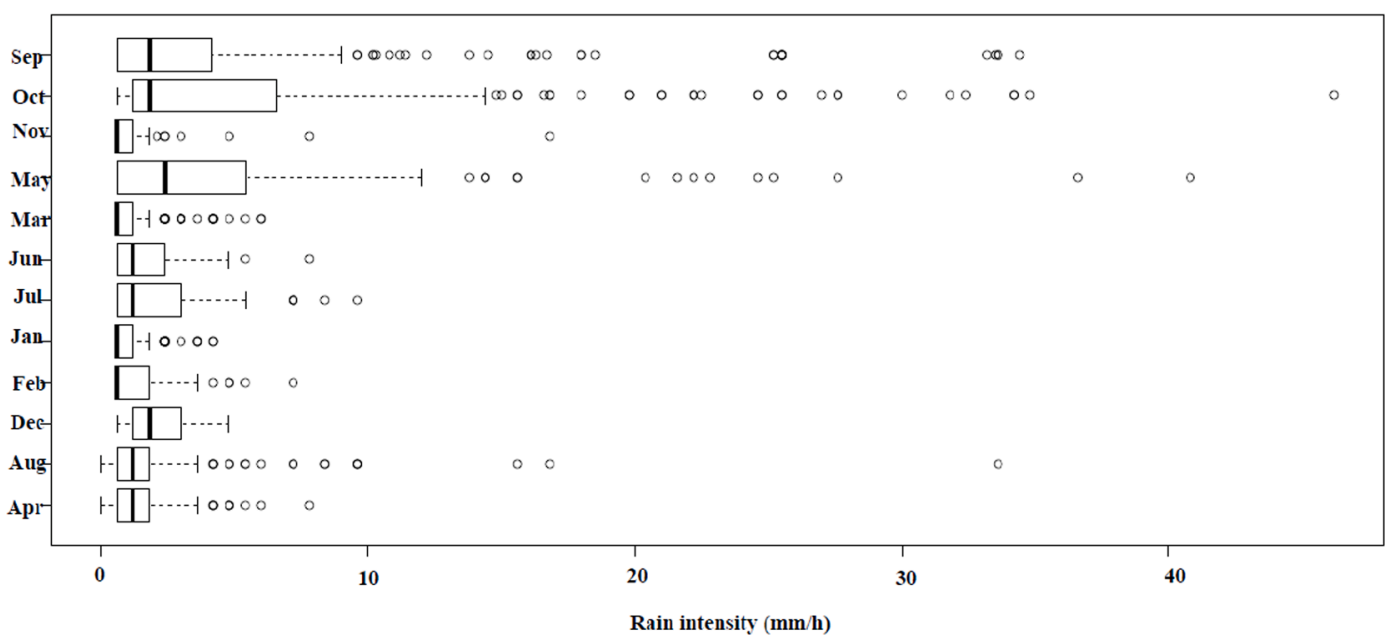

Fig 5. The frequency of rain intensity in the period between August 1, 2018 and July 31, 2019.

Table 7

Runoff amount measured using rain simulator in three conditions of soil water content and three rainfall intensities (RI).

\begin{tabular}{|c|c|c|c|c|c|c|c|c|c|}
\hline & \multicolumn{3}{|c|}{ Dry soil $(\theta<2 \%)$, WDPT $=50 \mathrm{~min}$} & \multicolumn{3}{|c|}{$\theta=4 \%, \mathrm{WDPT}=2 \mathrm{~min}$} & \multicolumn{3}{|c|}{$\theta=14-40 \%, \mathrm{WDPT}=-$} \\
\hline & $\mathrm{RI}=14 \mathrm{~mm} / \mathrm{h}$ & $\mathrm{RI}=27 \mathrm{~mm} / \mathrm{h}$ & $\mathrm{RI}=34 \mathrm{~mm} / \mathrm{h}$ & $\mathrm{RI}=14 \mathrm{~mm} / \mathrm{h}$ & $\mathrm{RI}=27 \mathrm{~mm} / \mathrm{h}$ & $\mathrm{RI}=34 \mathrm{~mm} / \mathrm{h}$ & $\mathrm{RI}=14 \mathrm{~mm} / \mathrm{h}$ & $\mathrm{RI}=27 \mathrm{~mm} / \mathrm{h}$ & $\mathrm{RI}=34 \mathrm{~mm} / \mathrm{h}$ \\
\hline Repetition 1 & 0 & 2.8 & 6.0 & 0 & 0 & 1.0 & 0 & 0 & 0 \\
\hline Repetition 2 & 0 & 2.5 & 4.0 & 0 & 0 & 0.7 & 0 & 0 & 0 \\
\hline Repetition 3 & 0 & 3.0 & 5.0 & 0 & 0 & 1.0 & 0 & 0 & 0 \\
\hline
\end{tabular}

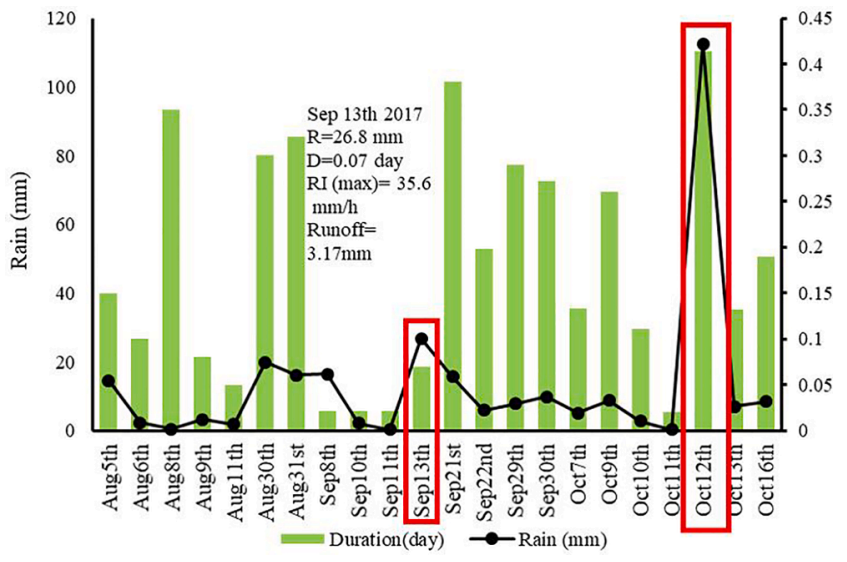

Fig 6. The amount of rain, duration of each rain event and the runoff simulated by the SWAP model from August 1st to October 31st 2017 (R: Rain, D: Duration, RI: Rain Intensity).

During the second period (November 2017 to April 2018), the measured water content ranged between 14.2 and $20 \%$. The simulation results of the model were consistent with laboratory findings and no runoff quantities were simulated. During these months (November to April), the intensity of the rains was less than the critical intensity (27 $\mathrm{mm} \cdot \mathrm{h}^{-1}$, according to the results of the rain simulator experiment) that initiates runoff. Also, field measurements and model simulation showed that soil water contents were larger than $14 \%$ in this period (Fig. 4). At these water contents, the soil is completely wettable and runoff is prevented (Table 6).

During the third period (May to July 2018), the soil water content ranged between 5 and $11 \%$. Although during this period soil water content was higher than in September and October, mild water repellency was observed. Therefore, the rain event $(32.5 \mathrm{~mm})$ that occurred on May 26th did cause runoff $(7.39 \mathrm{~mm})$. Although the rainfall amount on May 27th $(49 \mathrm{~mm})$ was higher, the intensity of the rainfall was lower. Concerning runoff, the duration and intensity of rain are important. When the duration and intensity of rain are large, the risk of runoff increases. This has been observed in the May rains. On May 26th, $32.5 \mathrm{~mm}$ of rain fell, and runoff was created. Although there was more rain (49 $\mathrm{mm}$ ) on May 27th, no runoff was generated. The main reason for this is the duration of the rain because the duration of the May 27th rain was 0.35 days, but the May 26th rain fell in less time (0.097 days) and the rain had less time to penetrate the soil and runoff was formed. Also, soil water contents were larger on May 27th due to the rainfall on a preceding day. Therefore, despite a large amount of rainfall on May 27, no runoff was simulated. Although the average and maximum rainfalls in May are higher than in September, SWAP simulated less runoff in May than in September. This is probably due to the higher soil water content in May. The results of runoff measurements in the laboratory confirm this.

\subsection{Soil evaporation}

Water repellency reduces the evaporation rate of the soil surface. Therefore, the results of the water balance table show that the amount of evaporation in repellent soils is less than in wettable soils (Table 5). The results of the cumulative evaporation simulated with SWAP and measured at different sand cylinders in the laboratory are depicted in Fig. 9. The results of laboratory measurements show that the repellent layer reduces the evaporation of water from the soil surface. The measurements also show that with increasing hydrophobicity of the surface layer, the water evaporation flux from the soil surface decreases. One can see that most of the evaporation had taken place from the surface of wetting samples (C3 and C4) and the extreme water repellent layer (C1) showed the lowest amount of evaporation from the soil surface (Fig. 9 (1)).

Fig. 9(2) shows the results of the amount of evaporation from the soil surface simulated with SWAP for the wettable and repellent samples. As 


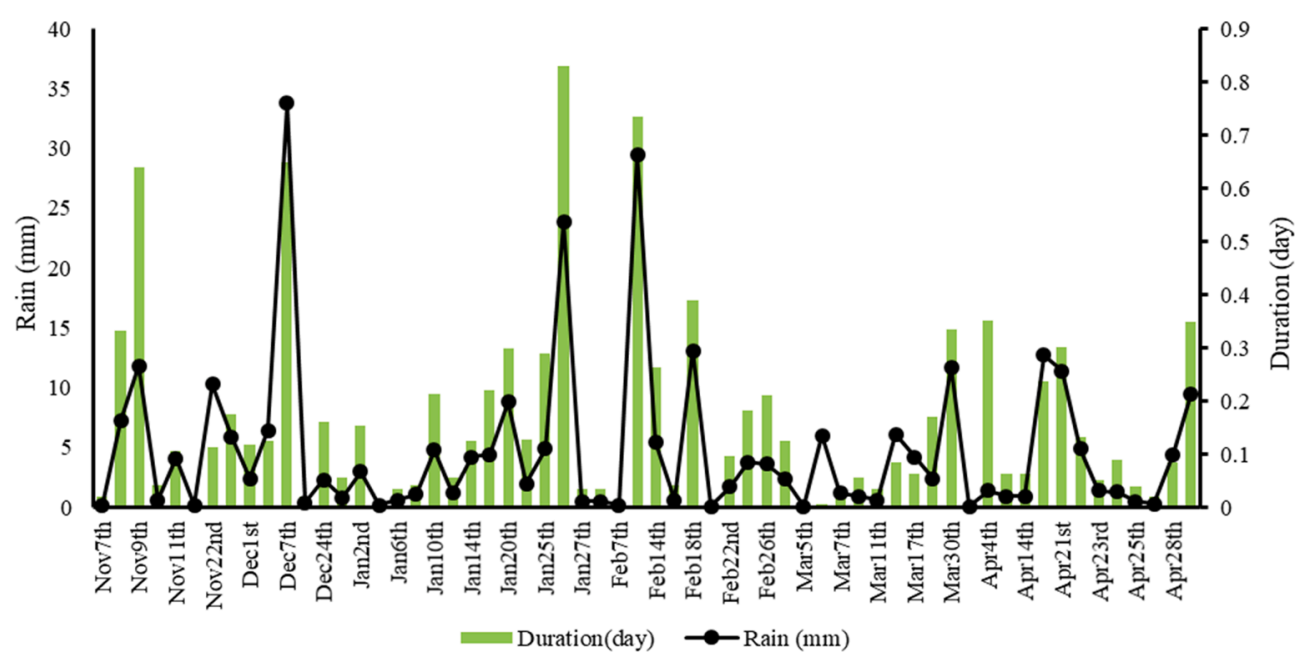

Fig 7. The amount of rain, duration of each rain event and the runoff simulated by the SWAP model during November 1th to April 30th 2018 (R: Rain, D: Duration, RI: Rain Intensity).

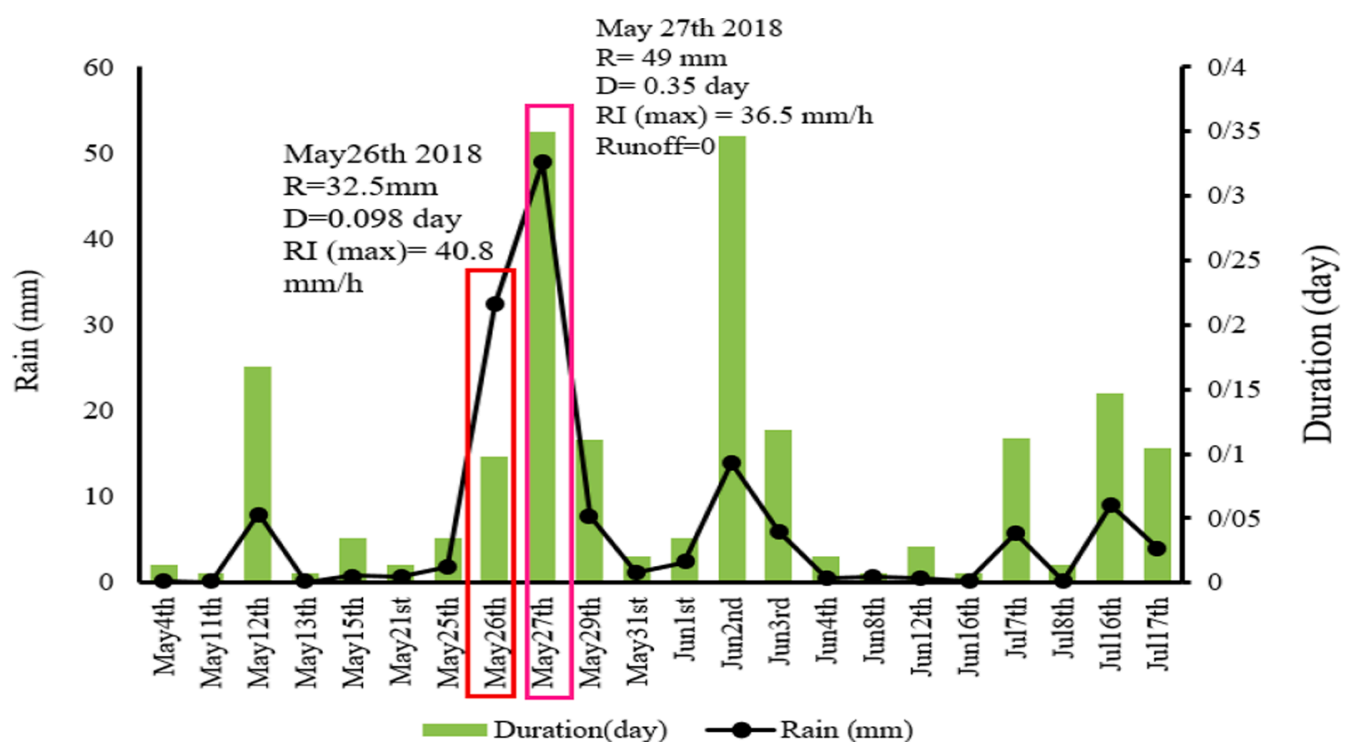

Fig 8. The amount of rain, duration of each rain event and the runoff simulated by the SWAP model during May 1st to July 31 st 2018 (R: Rain, D: Duration, RI: Rain Intensity).

can be seen, a similar trend has been obtained with laboratory findings. In the case of the repellent sample, the amount of evaporation from the soil surface has been reduced. This was caused by the lower water content in repellent soil as compared to the wettable soils. Fig. 9(2) shows that the amount of evaporation was simulated low from the 1 st to the 4th of August and then increased on the 5th of August. The meteorological data show that no rain fell from August 1st to 4th, and then, on the 5th and 6th of August, 14.5 and $2.3 \mathrm{~mm}$ of rain were recorded, respectively. This increased the soil moisture in the soil surface layer (Fig. 4.a). Therefore, due to the increase in soil moisture, we can expect an increase in soil evaporation on the 5th and 6th of August.

\section{Discussion}

\subsection{Simulation of soil water content}

At the study site, three soil layers were considered to a depth of 250 $\mathrm{cm}$. The soil was extremely water repellent above $15 \mathrm{~cm}$ depth, slightly water repellent at a depth between 15 and $40 \mathrm{~cm}$ and completely wettable in the deeper part of the soil $(40-250 \mathrm{~cm})$.
The simulation with measured soil hydraulic functions in the laboratory was representative of soil water fluxes in the field. Because in the field, soil water flow occurs only through preferential channels, the hydraulic conductivity measured in the laboratory was greater. This result is consistent with the findings of Ritsema et al. (2005) and Van Dam et al. (1990, 1996). Comparing modelling results with the field data and the lab experiment showed that, considering the preferential flow, SWAP could simulate the correct water flux in repellent soil. The result of the SWAP model was verified with in situ measurements of soil water content. Ahmad et al. (2002) used the same method for validation.

Wessolek et al. (2007) stated that the water flux in repellent soil could not be described with a traditional one-dimensional model such as SWAT. Of course, by modifying the model with the mobile-immobile concept, the model could provide somewhat accurate information about the mean percolation rate and evapotranspiration for situations with and without preferential flow.

The results obtained from the third simulation period (May to July) were similar to the first period (August to October). Although in this period the soil moisture was higher than the first period and moderate water repellency was observed, only a part of the bulk soil was active in 


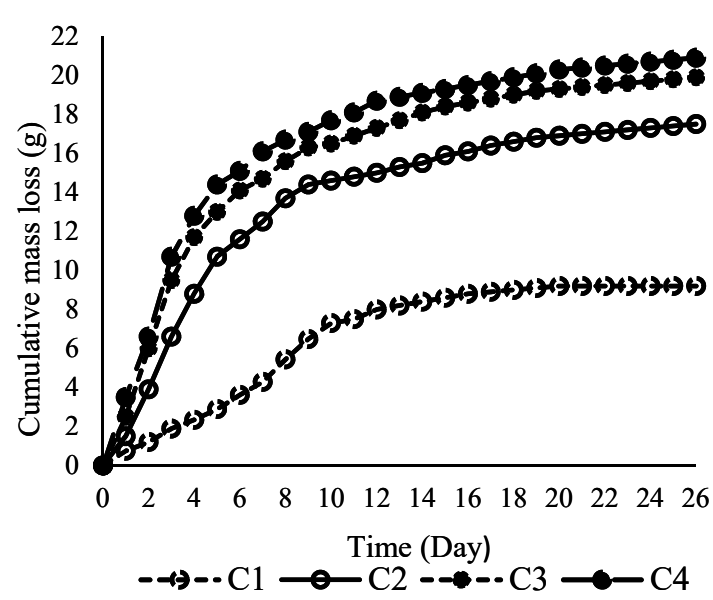

(1)

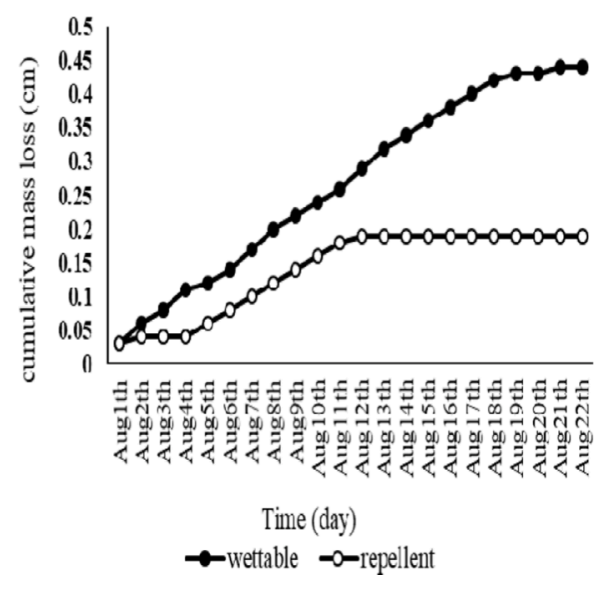

(2)

Fig 9. (1) Cumulative evaporation losses measured in the laboratory from (C1) $2 \mathrm{~cm}$ extremely repellent sand placed on top of wettable sand (C2) $2 \mathrm{~cm}$ slight repellent sand on top of wettable sand (C3, C4) completely wettable sand (2) Cumulative evaporation losses simulated by the SWAP model in wettable and repellent soil.

water transfer. Due to the smaller horizontal flow cross-section in repellent soil, the overall hydraulic conductivity in the field was less than in the laboratory. This is because in dry conditions when the soil is dry and repellent, the actual flow takes place through fingers. In this way, the acceleration of soil water flow occurs in the mobile part (Finger section).

Although from August until April, the bottom fluxes were less in the case of repellency (simulation 1), from August 31th to October 11th at a depth of $40-250 \mathrm{~cm}$, the model simulated more soil water content in the case of repellency. The soil at this depth $(40-250 \mathrm{~cm})$ was wettable. Probably the presence of repellency in the topsoil affected infiltration fluxes and accelerated the soil water flow into the mobile part (Finger section), and finally, considering the repellency, soil water content increased in deeper layers $(40-250 \mathrm{~cm})$. This result is in agreement with the findings of van Dam et al. (1996). They stated that water fluxes in repellent soil were more than wettable soil as a result of the movement of water through the preferential flow. Preferential flow in repellent soil increases soil water movement in finger parts, but overall, the water content is lower than in wettable soil. Also, Ritsema and Dekker (1994) stated that finger flow formed in repellent soils accelerates the transport of water toward the saturated zone.

\subsection{Soil water balances and runoff}

Field observations showed that soil hydrophobicity was not uniform throughout the simulation period. Therefore, for correct evaluation, the whole simulation period was divided into three periods. The results showed that by considering water repellency by entering the $F_{\text {mob }}$ parameter into the model, the soil water storage in the root zone would change when the $F_{m o b}$ changes. In the first period (August to October), extreme water repellency was measured at the depth of $0-15 \mathrm{~cm}$ and moderate soil water repellency was measured at the depth of $15-45 \mathrm{~cm}$. The values of $\mathrm{F}_{\mathrm{mob}}$ considered for these layers were 0.5 and 0.7 , respectively. In the second period (November to April), the soils were wettable in all layers and the values of $\mathrm{F}_{\mathrm{mob}}$ increased to one. The results showed that when the $\mathrm{F}_{\mathrm{mob}}$ increased, the amount of water storage also increased (from 5.59 to 8.97) (Table 5). In the third period, the soils became repellent again and a smaller value of $F_{\text {mob }}$ was entered in the model to account for soil water repellency. In this case, the amount of water storage also decreased (from 9.64 to 7.48 ) (Table 5). The reason is that when the $F_{\text {mob }}$ increases, the water in the immobile parts will be added to the water storage and when the $\mathrm{F}_{\mathrm{mob}}$ decreases, water lost to the immobile parts will decrease the water storage in the mobile parts.
These findings are consistent with the findings of Van Dam et al. (1996). The results of their research showed that water storage fluctuates due to different repellency conditions. They investigated the effect of preferential flow on soil water movement in the water repellent soils in the Netherlands. To demonstrate the effect of water repellency, they used a constant mobile fraction $(\mathrm{F}=0.6)$. The results of their research showed that during the dry summer, water storage decreased from 14 $\mathrm{cm}$ to $4 \mathrm{~cm}$. During the autumn and winter when the soils were wettable, this amount increased to 14 . From the spring to early summer (May to early July), Water storage fluctuated only between 14 and $9.5 \mathrm{~cm}$, because of slight water repellency.

The results show that the effects of water repellency are an important factor in the generation of runoff. When the repellency is ignored, simulations overestimate soil water content and underestimate runoff. The effect of hydrophobicity on runoff generation was not previously investigated by the SWAP model, so in this study, we were interested in surface runoff originating from intense rainfall. Accurate estimates of surface runoff require reliable schemes of infiltration and subsequent redistribution of water throughout the soil profile. Results of our measurements and experiments showed that surface runoff could be accurately simulated using the mobile-immobile concept for water repellent soil.

The results of the laboratory rain experiments showed that rain with an intensity greater than the critical amount $\left(27 \mathrm{~mm} \cdot \mathrm{h}^{-1}\right.$, determined in this soil) causes runoff when the soil is dry and repellent, but the same intensity of rain does not cause runoff when the soil is wettable. Along with the effective parameters in creating runoff, the duration of precipitation is an important factor. As the duration of rainfall decreases, rains with the same intensity and even less rain intensity can cause runoff.

Corona et al. (2013) stated that the difference in runoff amounts are related to rainfall intensities and initial soil moisture conditions. However, the effect of the initial soil moisture condition is different in repellent and wettable soil. In wettable soil, the amount of runoff increases with increasing initial soil moisture (Corona et al., 2013) but in repellent soil, the result is the opposite. With increasing soil moisture, the soil changes from repellent to wettable and water can penetrate the soil, thus reducing runoff. Soil water repellency has a significant effect on soil infiltration conditions. Therefore, if soil water repellency is not considered, an accurate estimate of runoff flow in these soils cannot be obtained.

Field observations and measurements showed that soil hydrophobicity and runoff caused by soil water repellency were dynamic 
phenomenon and depend on the season. Sheridan et al. (2007) investigated the effect of soil water repellency on runoff generation in clay loam forest soils in an Australian Eucalypt forest. They reported the seasonal fluctuations in runoff ratio in repellent finer-textured Eucalyptus forest soils in the summer months. They used computer simulations of infiltration-excess runoff. In this method, the runoff rate is very sensitive to the selection contact angle and there may be some error in the calculation of the contact angle.

Moody and Ebel (2014) used a numerical model (Hydrus 1-D) to estimate post-wildfire infiltration and runoff within the unsaturated zone. They stated that the time to start the run-off depends on the initial soil-water saturation deficit and soil wettability. Generally, wettability of soil particles seems to be a time- and moisture-dependent phenomenon. Zheng et al. (2017) investigated the hydrological behavior of synthetic water repellent soils in laboratory studies. To investigate the influence of wettability change on hydrological responses, they used flume tests at various scales under artificial rainfall. They stated that with increasing the soil water repellency, infiltration is inhibited and runoff is promoted.

\subsection{Evaporation}

Both laboratory measurements and model simulations show water repellency does reduce the evaporation from the soil. Repellent materials reduce evaporation by reducing the capillary force required to move water to the soil surface (Bachmann et al., 2001). Soil water repellency does affect the transfer of moisture in the soil as a capillary to the soil surface. Therefore, it is expected that the surface repellent layer will prevent the transfer of moisture to the soil surface, and as result, the reduction of water supply to the surface will reduce evaporation from the soil surface. Hallett (2008) stated that a repellent layer on the soil surface can create a barrier to capillary flow and thus reduce soil evaporation. The research of Rye and Smettem (2017) showed that the pattern of wetting in repellent soils is preferential flow and causes water transfer to the depth of the soil. Therefore, the amount of water in the topsoil decreases and as a result, evaporation decreases as compared to wettable soil. Shokri et al. (2009) stated that repellent layers reduce evaporation mass loss of hydrophobic layers due to the interruption of capillary flow.

The results of our study show that the soil evaporation rate decreases with increasing soil water repellency and the impact of the water repellent layer is related to the severity of the repellency. As the degree of hydrophobicity increases, the transfer of moisture through the capillary flow to the soil surface decreases, and as a result, the rate of evaporation decreases. These results are in agreement with the findings of Bachmann et al. (2001) and Lichner et al. (2020).

\section{Conclusion}

In general, to accurately describe the hydraulic behavior in soil water, the water repellency effect must be taken into account. In this study, a one-dimensional numerical adapted model SWAP 4.0 was applied to simulate soil moisture content, vertical soil water fluxes and runoff in the unsaturated zone. We investigated whether incorporating the degree of water repellency, by using the mobile-immobile concept, leads to better predictions of soil water content, runoff and evaporation in water repellent soils. The adapted method was assessed using field and laboratory measurements for unburned pinus plantations. The soil at our study site was extremely repellent during summer and early autumn and completely wettable from late autumn to spring.

The results of the amount of soil water content and runoff measured and simulated by SWAP show that an assumption of uniform flow in water repellent soil leads to an overestimation of soil water content, an underestimation of runoff and an overestimation of soil evaporation. After implementing water repellency in SWAP with the mobile-immobile concept, there was a good fit between measured and model- simulated data. Depending on the severity of water repellency, water enters the soil with a delay and causes more or less runoff. The most runoff was estimated by the model in October, but no runoff was observed from November to April.

Soil water repellency leads to a reduction of evaporation, which may be beneficial for vegetation. It concluded that the surface layers of water repellency, created by pine trees, can delay evaporation significantly for coarse-textured soils, which may be especially useful for plants in hot and dry periods in summer.

Previously, the effect of hydrophobicity on runoff generation was not investigated by the swap model. This study clearly confirmed that the adapted SWAP.4 model could accurately predict soil water content and runoff in water repellent soil and is a useful tool to investigate the effect of water repellency on soil hydraulic properties. The results show that the effects of water repellency are an important factor in the generation of runoff. However, further work is necessary to improve process knowledge about the impact of soil water repellency on runoff generation.

\section{Declaration of Competing Interest}

The authors declare that they have no known competing financial interests or personal relationships that could have appeared to influence the work reported in this paper.

\section{References}

Ahmad, M.-D., Bastiaanssen, W.G.M., Feddes, R.A., 2002. Sustainable use of groundwater for irrigation: a numerical analysis of the subsoil water fluxes Irrigation Drainage 51 (3), 227-241.

Allen, R.G., Pereira, L.S., Raes, D., Smith, M., 1998. Crop evapotranspiration. Guidelines for computing crop water requirements. Irrigation and Drainage Paper 56, FAO, Rome, Italy, $300 \mathrm{p}$.

Almendros, G., Martín, F., González-Vila, F.J., 1988. Effects of fire on humic and lipid fractions in a Dystric Xerochrept in Spain. Geoderma 42 (2), 115-127. https://doi. org/10.1016/0016-7061(88)90028-6.

Bachmann, J., Horton, R., van der Ploeg, R.R., 2001. Isothermal and Nonisothermal Evaporation from Four Sandy Soils of Different Water Repellency. Soil Sci. Soc. Am. J. 65 (6), 1599-1607. https://doi.org/10.2136/sssaj2001.1599.

Badia-Villas, D., Gonzalez-Perez, J.A., Aznar, J.M., Arjona-Garcia, B., Marti-Dalmau, C., 2014. Changes in water repellency, aggregation and organic matter of a mollic horizon burned in laboratory: Soil depth affected by fire. Geoderma 213, 400-407. https://doi.org/10.1016/j.geoderma.2013.08.038.

Balfour, V.N., 2015. Determining wildfire ash saturated hydraulic conductivity and sorptivity with laboratory and field methods. Catena. 135, 358-368. https://doi.org/ 10.1016/j.catena.2014.01.009.

Blackwell, P.S., 1993. Improving sustainable production from water repellent sands. Western Australia J. Agric. 34, 160-167. https://researchlibrary.agric.wa.gov.au/jo urnal_agriculture4/vol34/iss4/11.

Brooks, R.H., Corey, A.T., 1964. Hydraulic properties of porous media. Hydrol. Pap. No. 3. Colorado State Uni, Fort Collins.

Burdine, N.T., 1953. Relative permeability calculations from pore size distribution data. Trans. Am. Inst. Min. Metal. Pet. Eng. 198, 71-77.

Butzen, V., Seeger, M., Marruedo, A., de Jonge, L., Wengel, R., Rise, J.B., Casper, M.C., 2015. Water repellency under coniferous and deciduous forest Experimental assessment and impact on overland flow. Catena 133, 255-265. https://doi.org/ 10.1016/j.catena.2015.05.022.

Chan, K.Y., 1992. Development of seasonal water-repellency under direct drilling. J. Soil Sci. Soc. Am. 56, 326-329. https://doi.org/10.2136/ sssaj1992.03615995005600010054x.

Chau, H.W., Biswas, A., Vujanovic, V., Cheng Si, B., 2014. Relationship between the severity, persistence of soil water repellency and the critical soil water content in water repellent soils. Geoderma 221-222, 113-120. https://doi.org/10.1016/j. geoderma.2013.12.025.

Christiansen, J.E., 1942. Irrigation by sprinkling. University of California Agricultural Experimental Station. Berkley, CA, Bulletin, p. 670.

Corona, R., Wilson, T., D’Adderio, L.P., Porcu, F., Montaldo, N., Albertson, J., 2013. Four decades of Progress in Monitoring and Modeling of processes in the Soil-PlantAtmosphere System: Applications and Challenges: On the estimation of surface runoff through a new plot scale rainfall simulator in Sardinia, Italy. Procedia Environ. Sci. 19, 875-884. https://doi.org/10.1016/j.proenv.2013.06.097.

Daniel, N.R.R., Uddin, S.M.M., Harper, R.J., Henry, D.J., 2019. Soil water repellency: A molecular-level perspective of a global environmental phenomenon. Geoderma 338, 56-66. https://doi.org/10.1016/j.geoderma.2018.11.039.

Davies, B.E., 1974. Loss-on- Ignition as an estimate of soil organic matter. Soil Sci. Am. Proc. 38 (1), 150-151.

DeBano, L.F., 1981. Water Repellent Soils: A State of the Art. 
Deurer, M., Bachmann, J., 2007. Modeling water movement in heterogeneous waterrepellent soil: 2. A conceptual numerical simulation. Vadose Zo. J. 6 (3), 446-457. https://doi.org/10.2136/vzj2006.0061.

Doerr, S.H., Shakesby, R.A., Walsh, R.P.D., 1998. Spatial variability of soil hydrophobicity in fire-prone eucalyptus and pine forests. Portugal. Soil Sci. 163 (4), 313-324. https://doi.org/10.1097/00010694-199804000-00006.

Gee, G.W., Or, D., 2002. Particle-size analysis. In: Dane, J.H., Topp, G.C. (Eds.), Methods of soil analysis, part 4 - physical methods: Agronomy Monograph, vol. 9. ASA and SSA, Madison, WI pp, 255-293. https://doi.org/10.2136/sssabookser5.4.

Hallett, P.D., 2008. A Brief Overview of the Causes, Impacts and Amelioration of Soil Water Repellency - a Review. Soil Water Res. 3, S21-S29.

Hendricks, J.M.H., Dekker, L.W., van Zuilen, E.J., Boersma, O.H., 1988. Water and Solute movement through a water repellent sand soil with grass cover. In: Proceeding of 'Validation of flow and Transport Models for the unsaturated zone, Conf. Ruidoso, NM, pp. 131-146.

Klute, A., 1986. Method of Soil Analysis. Part. 1. Physical and Mineralogical Methods. Soil. Sci. of America. Madison, Wisconsin. USA. https://doi.org/10.1002/ gea.3340050110.

Kramers, G., van Dam, J.C., Ritsema, C.J., Stagnitti, F., Oostindie, K., Dekker, L.W., 2005. A new modelling approach to simulate preferential flow and transport in water repellent porous media: Parameter sensitivity, and effect on crop growth and solute leaching. Aust. J. Soil Res. 43, 371-382. https://doi.org/10.1071/SR04098.

Kroes, J.G., van Dam, J.C., Bartholomeus, R.P., Groenendijk, P., Heinen, M., Hendriks, R. F.A., Mulder, H.M., Supit, I., van Walsum, P.E.V., 2017. SWAP version 4. Theory description and user manual. Wageningen Unoversity.

Lassu, T., Seeger, M., Peters, P., Keesstra, S.D., 2015. The Wageningen rainfall simulator: set-up and calibration of an indoor nozzle-type rainfall simulator for soil erosion studies. Land Degrad. Develop. 26 (6), 604-612. https://doi.org/10.1002/ldr.2360.

Leelamanie, D.A.L., 2016. Occurrence and distribution of water repellency in size fractionated coastal dune sand in Sri Lanka under Casuarina shelterbelt. Catena 142, 206-212. https://doi.org/10.1016/j.catena.2016.03.026.

Lichner, L̆., Alagna, V., Iovino, M., Laudicina, V.A., Novák, V., 2020. Evaporation from soils of different texture covered by layers of water repellent and wettable soils. Biologia 75 (6), 865-872. https://doi.org/10.2478/s11756-020-00471-5.

Mao, J., Nierop, K.G.J., Dekker, S.C., Dekker, L.W., Chen, B., 2019. Understanding the mechanisms of soil water repellency from nanoscale to ecosystem scale: a review. J. Soils Sediments 19 (1), 171-185. https://doi.org/10.1007/s11368-018-2195-9.

Mirbabaei, S.M., Shabanpour Shahrestani, M., Zolfaghari, A.A., Taheri Abkenar, K., 2013. Relationship between soil water repellency and some of soil properties in northern Iran. Catena 108, 26-34. https://doi.org/10.1016/j.catena.2013.02.013.

Moody, J.A., Ebel, B.A., 2014. Infiltration and Runoff Generation Processes in Fireaffected Soils. Environ. Sci. 28 (9), 3432-3453. https://doi.org/10.1002/hyp. v28.910.1002/hyp.9857.

Mualem, Y., 1976. A new model for predicting the hydraulic conductivity of saturatured porous media. Water Resour. Res. 12, 513-522.

Nunes, J.P., Malvar, M., Benali, A.A., Rial Rivas, M.E., Keizer, J.J., 2016. A simple water balance model adapted for soil water repellency: application on Portuguese burned and unburned eucalypt stands. Hydrol. Process. 30 (3), 463-478. https://doi.org/ 10.1002/hyp.v30.310.1002/hyp.10629.

Philip, J.R., 1957. Theory of infiltration. In: Chow, V.T. (Ed.), Advances in Hydroscience, vol. 5. Academic Press, New York, pp. 215-296.

Pullman, W.A., 2012. Decagon Devices. Minidisk Infiltrometer User's Manual Version 10; Decagon Devices.

Rezanezhad, F., Vogel, H.J., Roth, K., 2006. Experimental study of fingered flow through initially dry sand. Hydrol. Earth Syst. Sci. 3, 2595-2620. https://doi.org/10.5194/ hessd-3-2595.

Ritsema, C.J., Dekker, L.W., 1994. How water moves in a water repellent sandy soil. Water Resour. Res. 30, 2519-2531. https://doi.org/10.1029/94WR00749.

Ritsema, C.J., Van Dam, J.C., Dekker, L.W., Oostindie, K., 2005. A new modelling approach to simulate preferential flow and transport inwater repellent porous media: model structure and validation. Aust. J. Soil Res. 43, 361-369. https://doi.org/ 10.1071/SR05054.

Robichaud, P.R., Lewis, S.A., Ashmun, L.E., 2008. New procedure for sampling infiltration to assess post-fire soil water repellency. Research Note, RMRS-RN-33US Department of Agriculture, Forest Service, Rocky Mountain Research Station, Fort Collins, Colorado 14.

Rye, C.F., Smettem, K.R.J., 2017. The effect of water repellent soil surface layers on preferential flow and bare soil evaporation. Geoderma 289, 142-149. https://doi. org/10.1016/j.geoderma.2016.11.032.

Sheridan, G.J., Lane, P.N.J., Noske, P.J., Sherwin, C.B., Nyman, P., 2007. Runoff Generation from Water Repellent Soils with High Spatial and Temporal Variability in Infiltration Capacity. MODSIM07 - Land, Water and Environmental Management: Integrated Systems for Sustainability. Proceedings, 1245-1251.

Shokri, N., Lehmann, P., Or, D., 2009. Characteristics of evaporation from partially wettable porous media. Water Resour. Res. 45, W02415. https://doi.org/10.1029/ 2008WR007185.

Smith, R.E., 2002. Infiltration theory for hydrologic applications. Water Resources Monograph 15. American Geophysical Union, Washington, D.C., p. 212

van Dam, J.C., Feddes, R.A., 2000. Numerical simulation of infiltration, evaporation and shallow groundwater levels with the Richards equation. J. Hydrol. 233 (1-4), 72-85. https://doi.org/10.1016/S0022-1694(00)00227-4.

Van Dam, J.C., Groenendijk, P., Hendriks, R.F.A., Kroes, J.G., 2008. Advances of Modeling Water Flow in Variably Saturated Soils with SWAP. Vadose Zone J. 7 (2), 640-653. https://doi.org/10.2136/vzj2007.0060.

Van Dam, J.C., Hendrickx, J.M.H., van Ommen, H.C., Bannink, M.H., van Genuchten, M. Th., Dekker, L.W., 1990. Water and solute movement in a coarse-textured water repellent field soil. J. Hydrol. 120, 359-379. https://doi.org/10.1016/0022-1694 (90)90159-U.

van Dam, J.C., Wösten, J.H.M., Nemes, A., 1996. Unsaturated soil water movement in hysteretic and water repellent field soils. J. Hydrol. 184 (3-4), 153-173. https://doi. org/10.1016/0022-1694(95)02996-6.

van Genuchten, M.Th., Nielsen, D.R., 1985. On describing and predicting the hydraulic properties of unsaturated soils. Ann. Geophys. 3, 615-628.

Van Genuchten, M.Th., 1980. A close form equation for predicting the hydraulic conductivity of unsaturated soils. Soil Sci. Soc. Am. J. 44, 892-898. https://doi.org/ 10.2136/sssaj1980.03615995004400050002x.

Vereecken, H., Weynants, M., Pachepsky, Y., Schaap, M.G., Van Genuchten, M.Th., 2010. Using Pedotransfer Functions to Estimate the van Genuchten-Mualem Soil Hydraulic Properties: A Review. Vadose zone J. 9, 795-820. https://doi.org/10.2136/ vzj2010.0045.

Wallach, R., 2010. Effect of soil water repellency on moisture distribution from a subsurface point source. Water Resour. Res. 46, W08521. https://doi.org/10.1029/ 2009WR007774.

Weninger, Th., Filipovic, V., Mesic, M., Clothier, B., Filipovic, L., 2019. Estimating the extent of fire induced soil water repellency in Mediterranean environment. Geoderma 338, 187-196. https://doi.org/10.1016/j.geoderma.2018.12.008.

Wessolek, G., Schwarzel, K., Greiffenhagen, A., Stoffregen, H., 2007. Percolation characteristics of a water-repellent sandy forest soil. Eur. J. Soil Sci. 59 (1), 14-23. https://doi.org/10.1111/j.1365-2389.2007.00980.x.

Yates, S.R., van Genuchten, M.Th., Warrick, A.W., Leij, F.J., 1992. Analysis of Measured, Predicted, and Estimated Hydraulic Conductivity Using the RETC Computer Program. Soil Sci. Soc. Am. J. 56, 1024-1030. https://doi.org/10.2136/ sssaj1992.03615995005600020003x.

Zhang, Renduo, 1997. Determination of soil sorptivity and hydraulic conductivity from the disk infiltrometer. Soil Sci. Soc. Am. J. 61 (4), 1024-1030. https://doi.org/ 10.2136/sssaj1997.03615995006100040005x.

Zheng, S., Lourenço, S.D.N., Cleall, P.J., Chui, T.F.M., Ng, A.K.Y., Millis, S.W., 2017 Hydrologic behavior of model slopes with synthetic water repellent soils. J. Hydrol. 554, 582-599. https://doi.org/10.1016/j.jhydrol.2017.09.013. 